\title{
Preliminary Review on Function, Needs and Approach of Underground Research Laboratory for Deep Geological Disposal of Spent Nuclear Fuel in Korea
}

\section{사용후핵연료 심층처분을 위한 지하연구시설(URL)의 필요성 및 접근 방안}

Dae-Seok Bae ${ }^{1 *}$, Yong-Kwon Koh ${ }^{1}$, Sang-Jin Lee ${ }^{2}$, Hyunjoo-Kim ${ }^{2}$ and Byong-Il Choi ${ }^{2}$

${ }^{1}$ Korea Atomic Energy Research Institute, 989-111 Daedeok-daero, Yuseong-gu, Daejeon, Korea

${ }^{2}$ Korea Radioactive Waste Management Company, 89 Bukseong-ro, Kyungju, Korea

배대석 ${ }^{*}$, 고용권 ${ }^{1}$, 이상진 ${ }^{2}$, 김현주 $^{2}$, 최병일 ${ }^{2}$

1 한국원자력연구원, 대전광역시 유성구 대덕대로 989번길 111

2 한국방사성폐기물관리공단, 경상북도 경주시 북성로 89

(Received May 13, 2013 / Revised June 24, 2013 / Approved June 25, 2013)

This study gives a conceptual and basic direction to develop a URL (underground research laboratory) program for establishing the performance and safety of a deep geological disposal system in Korea. The concept of deep geological disposal is one of the preferred methodologies for the final disposal of spent nuclear fuel (SNF). Advanced countries with radioactive waste disposal have developed their own disposal concepts reasonable to their social and environmental conditions and applied to their commercial projects. Deep geological disposal system is a multi-barrier system generally consisting of an engineered barrier and natural barrier. A disposal facility and its host environment can be relied on a necessary containment and isolation over timescales envisaged as several to tens of thousands of years. A disposal system is not allowed in the commercial stage of the disposal program without a validation and demonstration of the performance and safety of the system. All issues confirming performance and safety of a disposal system include investigation, analysis, assessment, design, construction, operation and closure from planning to closure of the deep geological repository. Advanced countries perform RD\&D (research, development \& demonstration) programs to validate the performance and safety of a disposal system using a URL facility located at the preferred rock area within their own territories. The results and processes from the URL program contribute to construct technical criteria and guidelines for site selection as well as suitability and safety assessment of the final disposal site. Furthermore, the URL program also plays a decisive role in promoting scientific understanding of the deep geological disposal system for stakeholders, such as the public, regulator, and experts.

Key words: Spent Nuclear Fuel, Deep geological repository, Multi-barrier disposal system, NBS(natural barrier system), EBS(emgineered barrier system), URL(underground research laboratory)

사용후핵연료 최종처분을 위해 심층처분은 세계적으로 가장 선호되는 방법이다. 이를 위해 선진국들은 자국 여건에 가장 잘 부합되는 고유의 처분시스템 개발에 주력하고 있거나, 일부 확보하여 상용처분사업에 적용하고 있다. 현재까지 알려진 대부 분의 심층처분시스템은 공학적 및 천연방벽으로 구성된 다중방벽시스템이다. 이들 처분시스템은 수 천 년 수 십만 년 이상 의 성능기간이 대하여 성능 - 안전성의 입증이 확인되어야 후속 상용처분사업에 적용 가능하다. 입증 현안과제들은 처분시 스템의 상능 - 안전성 확보를 위해 수행되는 모든 행위 즉, 조사, 분석, 해석, 평가, 설계, 건설, 운영 및 폐쇄에 이르는 전 과 정에 있어서 추진 과정과 결과에 대한 실현 가능성과 실증에 필요한 내용들이 해당된다. 이를 위해 대부분의 선진국들은 자 
Dae-seok Bae. et al : Preliminary Review on Function, Needs and Approach of Underground Research Laboratory for Deep Geological Disposal of Spent Nuclear Fuel in Korea

국내 분포하는 대표적인 선호암종 지역에서 지하연구시설(URL)을 건설하여 실증 - 시연프로그램을 수행하거나 완성단계에 있다. 이 과정과 결과들은 후속되는 최종처분장 부지선정 과정에 평가기준으로 활용될 것이며, 최종처분시설의 성능 · 안전 성평가에 필수적으로 적용하게 된다. 지하연구시설은 또한 규제-일반대중-전문가 등 다양한 이해당사자들로 하여금 심층처 분의 안전성 수준에 대한 이해제고와 토론의 마당으로서 핵심적인 역할과 기능을 할 것으로 기대된다.

중심단어 : 사용후핵연료, 심지층처분장, 다중방벽시스템, 천연방벽, 공학적방벽, 지하연구시설

*Corresponding Author. E-mail: ndsbae@kaeri.re.kr, Tel: +82.42.868.2030

\section{1.서 론}

우리나라의 사용후핵연료의 국가관리와 관련하여 가장 최근의 정책 결정 사안은 제4차 원자력진흥위원회(2012.11) 의 결정이다[1]. 이에 의하면 "공론화위원회를 구성하여 공 론화과정을 거쳐 2014년까지「사용후핵연료국가관리기본 계획」을 수립하고, 2015년 이후 사용후핵연료중간저장시 설(이하 중간저장시설) 건설을 위한 후보부지 선정업무에 착 수한다"는 것이다. 추가적으로, 그간의 공론화포럼의 제안에 근거하여 중간저장시설 운영의 잠정적인 시기를 2024년을 목표로 하고, 중간저장시설의 운영 기간을 2050년까지로 예 상하고 있다. 한편 2050년은, 사용후핵연료를 중간저장시설 에서 최종처분장으로 운반을 시작해야 하는 시점으로 이해 된다. 이러한 목표 시점의 결정은 중간저장시설의 규모 및 운 영 방안에 대한 개념의 확립과 함께 최종처분장 운영을 의미 하는 것이다. 결국 사용후핵연료의 적정하고 효율적인 관리 를 위해서는 국가관리기본계획 수립 과정에 최종처분에 대 한 장기관리 개념이 반드시 연계 · 고려되어야만 대내외적으 로 그 정책적 신뢰성을 확보할 수 있을 것이다.

사용후핵연료와 방사성폐기물은 현세대의 책임 하에 안 전한 관리에 대한 대책과 처리에 대해 보장하여야 한다. 현 재 세계적으로 이들의 최종 처분방식은 인간생태계로부터 격 리시켜 심부지하에 처분하는 방법이 가장 선호되고 있다. 고 준위폐기물의 심층처분은 지하갱도 혹은 공학적시설, 폐광산, 및 심부시추공처분 등의 처분방법들을 통칭하는 의미로서, 일 정 운영기간 동안 지표 혹은 지하의 처분시설에서 이들의 능 동적관리가 가능하다. 각국의 고준위폐기물 심층처분개념으 로서 고유처분시스템은 공학적방벽(EBS: engineered barrier system) 및 천연방벽(NBS: natural barrier system)으로 구성되 는 다중방벽개념을 수용하고 있다.

한편, 발전용원자로 역시 동일한 다중방벽개념으로써, 60 년 내외의 수명 기간 동안 원자로 및 관련 시스템 등 현
재 기술 수준을 토대로 공학적방벽의 안전성을 보장하는 것 을 목표로 한다. 이에 비해서 심층처분시스템은 1,000 년 10,000 년 내외의 성능기간을 요구하는 공학적방벽과, 10 만 년 이상의 성능기간에 대하여 천연방벽의 성능이 각각 보장 됨을 입증하여야 한다 $[2,3,4]$. 특히 천연방벽의 핵종 격리기 능과 핵종이동 지연기능은 새로운 개념이나 실물의 창조 혹 은 개발로 확보되는 것이 아니다. 오로지 자연환경이 가지고 있는 특성을 대상으로 조사·분석 · 평가 등을 통하여 이러 한 기능을 발견·규명함으로써 성능·안전성을 확인 및 정 의하는 접근 방식이다. 이와 같은 개념적 차별성이 심층처분 사업을 공학적 접근방법이 아닌 연구·기술개발 과제 수행 방식이라는 근본적인 차이라 할 수 있다.

심층처분을 위한 처분사업에 있어서 해외 선진국들의 사 례를 보면, 가장 난제는 최종처분장 후보부지선정 업무이다. 후보부지선정 업무의 추진을 위해서 준비하여야 할 기본적 인 현안과제 중의 하나는 처분사업의 안전성 입증과 이에 대 한 국민이해 제고와 신뢰도 확보이다. 이들 목표 달성을 위 해 우선적으로 필요로 하는 준비 업무는 자국 고유처분시스 템 구축과 이의 성능 - 안전성을 입증하는 것이다. 이러한 입 증과정을 통해서 처분사업에 대한 객관성과 신뢰성을 확보 하도록 단계적 접근방안을 수립 및 시행하여야 할 것이다. 이의 목표는 URL (underground research laboratory: 지하 연구시설)을 이용하여 고유처분시스템의 성능 - 안전성에 대 한 실증 - 시연 과정을 통하여 달성되는 것이다. 따라서 심층 처분에 대한 종합계획 수립과 병행하여 URL에 대한 전반적 인 이해가 선행되어야 할 것이다: 즉, URL의 기능과 역할은 무엇인가; URL은 왜 필요한가; URL을 이용한 주요 현안과제 는 무엇인가; URL은 언제 착수하며 목표와 그 예상 달성 시 점은 언제인가; 그리고 URL 과업을 위해 지금 무엇을 해야 하는가 등이다.

본 연구는 사용후핵연료 국가관리기본계획 수립을 위한 공론화단계 진입에 즈음하여, 사용후핵연료 관리와 연계하 
Dae-seok Bae. et al : Preliminary Review on Function, Needs and Approach of Underground Research Laboratory for Deep Geological Disposal of Spent Nuclear Fuel in Korea

여 심층처분과 함께 우리나라에서 URL의 위상을 정립하고 향후 전개되어야 할 방향 설정에 조그마한 길잡이가 되고 국 민이해제고 측면에서 도움이 되고자 수행하였다.

\section{URL의 기능과 역할}

\section{$2.1 \mathrm{URL}$ 개요 및 역사}

\subsubsection{URL 개요}

방사성폐기물처분 분야에서 URL이라함은 『방사성폐기 물 처분장개발 프로그램』 (RDP: repository development program)을 지원하기 위한 제반 행위로서 처분시스템의 성 능·안전성에 대한 현장 실증·시연, 예비안전성평가, 처분 장 건설 및 운영 기술실증 등과 함께, 지하심부 지질특성 조 사·해석기술 개발, 처분성능 · 안전성 관련 기술개발, 전문 가 양성 - 훈련, 대국민 교육홍보 등이 종합적으로 이루어지 는 지하시설이라고 정의하고 있다[5].

URL의 유형은 크게 G(generic)-URL, PBG(purposed built generic)-URL 및 SS(site specific)-URL 등으로 분류되 며, 세계적으로 이들 시설의 기반암 지질은 크게 결정질암류 (crystalline), 이질암류(argillite), 암염(rock salt) 및 응회암 류(tuff) 등으로 구성된다(Table 1). 일반적으로 G-URL은 선 발 국가들이 폐기물처분연구 초기단계에서 시도한 유형으로 서 자국의 대표적인 선호암종 분포지역에 위치하는 기존 지 하공간 시설을 활용한 것이 특징이다. G-URL의 특성 상 기 존 폐광산 등을 이용하여 대부분 기존 갱도 주변에서 새로운 공간을 확보하여 암반의 온도, 역학, 수리 및 화학적 부문의 심부지질환경특성과 이들 요소간 상호 연계작용에 관한 연 구에 관심을 보였다. 하지만 폐광지역은 지질학적으로 취약 한 영역이 발달할 뿐만 아니라, 불규칙하고 추적하기 어려운 채굴적, 초기상태의 지질조건이 상당한 범위까지 교란되어 있다. 따라서 실제 처분환경에 대하여 다양한 이해계층의 이 해제고와 고유처분시스템의 성능 - 안전성에 대한 실증 - 시 연활동 공간으로서 부적절하다[6]. 이들 시설들은 기존 시설 활용 측면에서 효율적이지만, 대부분 1990년대 초 중반에 PBG-URL로 전환하는 경향을 보인다.

PBG-URL은 자국의 고유처분시스템 개발과 병행하여 시 설개발 후 처분시스템의 성능 - 안전성 분야의 실증 - 시연 측 면에 집중하였다. 주로 수직갱도 유형을 추구하였지만 Aspo $\mathrm{HRL}$ 의 경우 $[7,8]$, 섬 및 주변 생태환경의 교란을 최소화하기 위하여 육지로부터 해저를 통과하는 진입터널을 이용하여 접근하였으며, 섬 내부에 수직갱도를 설치하여 환기용 및 출
입용도로 계획하였다. 일본의 경우, MIU 및 Horonobe URL 등 두 개의 시설을 계획 · 건설 중이다[9](Table 1).

SS-URL은 최종처분장부지 내에서 처분시설의 건설허 가 신청을 위한 시설로 활용하였으며, Onkalo URL과 같이 PBG-URL에서 실증 - 시연한 현안과제를 감안하여 일부 항 목에 대하여 선별적으로 시행하였다[10]. 또한 처분장배치계 획과 조화를 이루어 처분시설의 일부로서 수용하였다. 미국 의 경우 Yucca Mt. 은 예상 처분장 영역 인근에 $\mathrm{ESF}$ 를 건설하 여 처분시스템의 실증 및 시연 관련 연구를 수행하였다[11].

\subsubsection{URL의 역사}

URL의 역사는 1958년부터 1972년까지 미국 Kansas의 Lyons에 있는 "project salt vault"를 시작으로 40 여년 이상의 역사를 가지고 있다(Table 1). ORNL Review에 의하면, 1960 년대 초반 ORNL 과학자들은 실제 처분모의시험을 시도하였 으나 1972년 캔사스주 당국의 반대로 중지되었다. 1960년대 중반부터 심층처분개념의 대두로 1980년대에 들어 G-URL 에 대한 관심이 증대되었다. 기본적으로 G-URL은 방사성폐 기물 처분연구와 관련 기술개발을 위한 시설로서, 초기의 URL은 주로 폐광산을 이용하였다.

$\mathrm{OECD} / \mathrm{NEA}$ 국제공동연구로 추진된 Stripa Project는 1980년부터 1992년까지 수행되었다. 이 Project에는 캐나다 (AECL), 핀란드(TVO, IVO), 프랑스(ANDRA), 일본(PNC), 스페인(JEN), 스웨덴(SKB), 스위스(Nagra), 영국(UK DoE), 미국(US DOE) 등이 참여하였다. 연구대상 암종은 노르웨이, 스웨덴, 핀란드 및 러시아 등에 걸쳐 분포하는 결정질심성암 인 화강암으로 구성되는 스칸디나비아 순장지(shield)를 대 상으로 하였다[5].

1980년대의 SS-URL은 IAEA에서 On-site URL과 동일한 용어로 제 2 세대 URL로 정의하고 있다. 벨기에는 연성 점토 암에 대한 SS-URL 프로젝트를 1985년부터 수행 중에 있으나, 실제로는 1974년 벨기에지질연구소가 Boom clay를 후보암 종으로 선정할 시점부터 시작되었다고 볼 수 있다. 1990년대 에 들어 기존의 R\&D 차원에서 실제 실행 프로그램을 적용하 려는 변화가 일기 시작했다.

\section{$2.2 \mathrm{URL}$ 의 기능과 역할}

URL의 기능과 역할을 고려할 때, 당연히 처분장개발 프 로그램의 단계 별 URL의 역할은 사업수행, 규제 및 지역주 민(국민) 측면 등 다양한 측면에서 접근할 수 있다[11, 12] (Table 2, 3). 
Dae-seok Bae. et al : Preliminary Review on Function, Needs and Approach of Underground Research Laboratory for Deep Geological Disposal of Spent Nuclear Fuel in Korea

Table 1. Status of URLs over the world

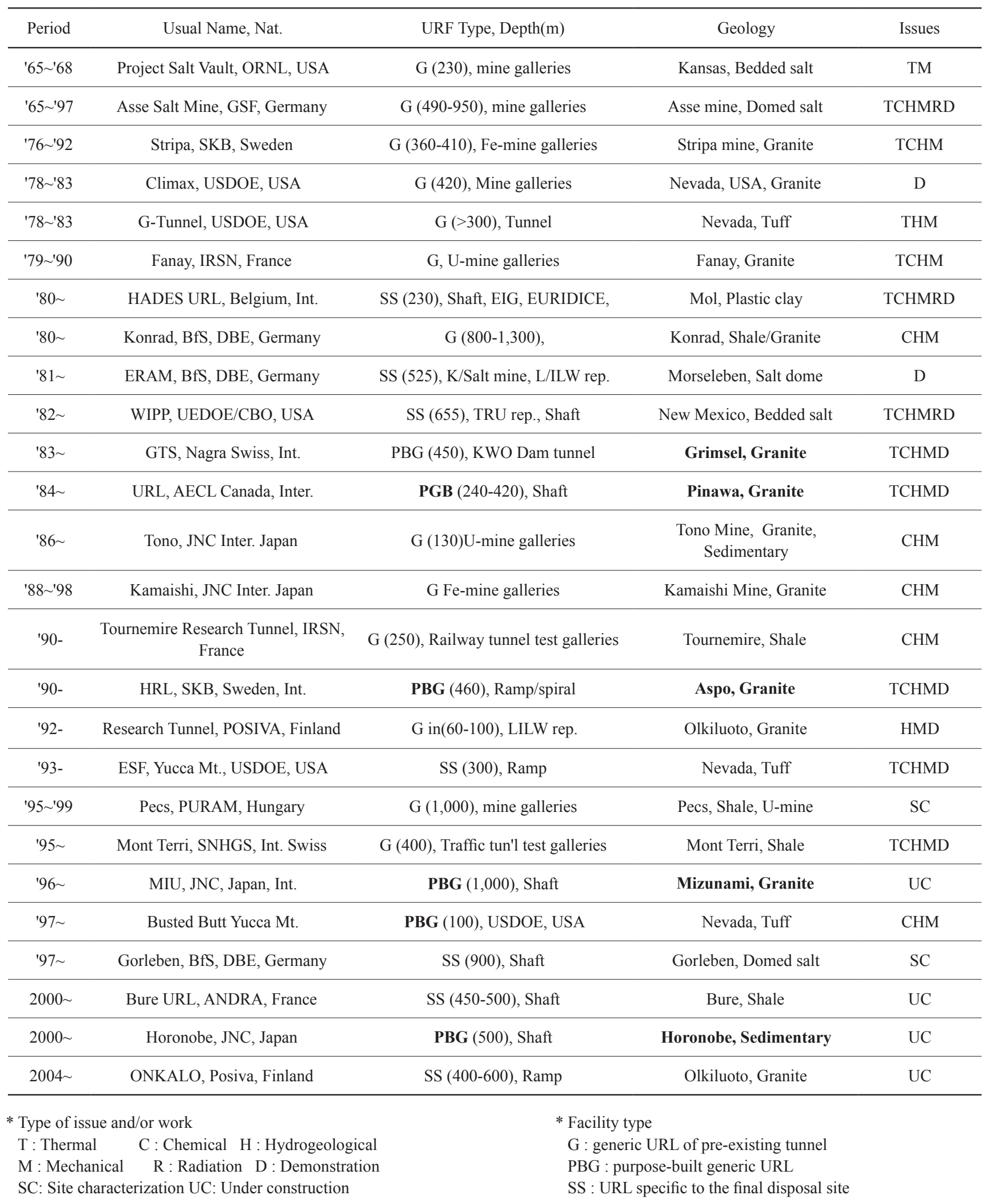


Dae-seok Bae. et al : Preliminary Review on Function, Needs and Approach of Underground Research Laboratory for Deep Geological Disposal of Spent Nuclear Fuel in Korea

\subsection{1 사업자 측면}

G-URL에서 수행한 일부 현안과제에 대하여 SS-URL에 서 다시 수행 할 수도 있으나, 두 개 유형의 URL에서 수행 하는 내용은 동일한 현안은 아니다. RDP의 진행 단계에 따 라 URL이 기여하는 역할에 대하여 RDP 수행 단계 별로 검 토하기 위해서 다음과 같이 사업 측면에서 크게 5개 단계로
구분할 수 있다.

a 종합계획 수립 및 처분시스템개발 단계

- 처분시설개발 기본방향 - 종합수행계획 수립, 처분개

념 개발, 고유처분시스템 초안 개발

- 사업자 및 규제 측면 관련 제도 정비 또는 확립(필요 시)

Table 2. Objectives of the work carried out in both generic and site-specific URLs

Generic/PBG-URL
SS-URL
- Develop disposal concepts

- Test methods for characterization and monitoring

- Develop linkage between descriptive/ conceptual and numerical models describing near-field behaviour

- Develop linkages between characterization parameters measured in boreholes (basically 1D) and those measured in the URL (2D and 3D)

- Develop understanding of sensitivity of rock mass performance to variability in measured characterization parameters

- Develop and test methods for constructional components and construction techniques

- Test components of the disposal system under realistic conditions

- Test alternative disposal and operational options

- Build technical confidence

- Develop and possibly demonstrate industrial-scale project

- Build national, multi-disciplinary team

- Develop experience and know-how

- Foster international co-operation
- Site evaluation and confirmation

- Characterization of geosphere immediately adjacent to repository

- Identification of suitable volumes/blocks of rock and detailed design and repository layout

- Reduction in inherent conservatism in conceptual and safety assessment models by collection of additional in situ data, testing of models, etc.

- Monitoring of near-field responses of the repository for regulatory purposes

- Demonstration of technology and techniques (and maintenance of up-to-date testing and interpretation techniques)

- Detailed design and testing of operational aspects

- Non-technical confidence building

- Address some of the Environmental Impact Assessment issues

- Continuation of surface-based investigations before repository construction

- Test flexibility of repository design and design-as-you-go (if that is the policy)

Table 3. Characteristics of the work types which can be carried out in generic and site-specific URLs and the constraints that apply to this work

\begin{tabular}{ll}
\hline \multicolumn{1}{c}{ Generic/PBG-URL } & \multicolumn{1}{c}{ SS-URL } \\
\hline - Essentially a research-based program & - Baseline conditions confirmed and geosphere monitoring system \\
- Opportunity for training in characterization techniques and R\&D & in place before construction \\
- Allows selection to be made between and demonstration of & - Construction of URL determined by repository concept and other \\
construction techniques & site conditions \\
- Development of testing methodologies & - Characterization of host rock and development of up-scaling rules \\
- Development of generic database & to a larger area \\
- Invasive methods for characterization and R\&D permitted & - Collection of host rock-specific data \\
- Testing of safety assessment models & - Perturbations to host rock minimized \\
- Testing of monitoring strategies & - Programme linked specifically to safety assessment requirements \\
& for licensing \\
\hline
\end{tabular}


Dae-seok Bae. et al : Preliminary Review on Function, Needs and Approach of Underground Research Laboratory for Deep Geological Disposal of Spent Nuclear Fuel in Korea

- 처분 선호암종 결정 및 처분관련 조사·시험·해석· 평가 · 시험 기술개발

- 처분시스템 관련 성능 · 안전성 부문 정성 · 정량적 성 능·안전성 요건 정의 및 개발

- 고유처분시스템(초안)의 수정 보완 및 실증용 처분시 스템개발(upgrade)

- 고유처분시스템 성능 · 안전성 실증·시연 프로그램 수립 및 착수

- 최종처분장 후보부지선정 기본방향 수립

- 처분시스템 성능 - 안전성실증 및 최종처분장 후보부 지선정 단계

- URL 시설 이용 고유처분시스템 성능 - 안전성 실증 시연 및 safety case 개발

- 처분장 부지요건 및 후보부지 평가 기술지침 개발 및 구축

- 후보부지 선정을 위한 종합프로그램 개발, 후보 부지 선정 평가 및 결정

- 최종처분장부지 특성평가(처분적합성평가)프로그램 개발

- SS-URL 이용 최종처분장 부지특성평가 및 안전성 평 가단계

- 최종처분장부지 내 SS-URL 건설 및 심층지질특성 규 명

- 실증 - 시연(완충재, 뒤채움재 및 회수기술) 등과 관련 한 일련의 업무 병행 수행

- 최종처분장부지에서 generic모델 검증, 실제 자료 이 용한 모델 보완 및 불확실성 저감

- 부지특성을 반영한 처분장부지 적합성평가, 최적 설계 및 처분장부지 안전성평가가 수행

- 처분시설 건설허가신청 및 성능 - 안전성 심사(규제기 관), 처분장부지 환경감시 수행

- 최종처분장 건설단계

- 최종처분장 건설

- 밀봉 및 폐쇄 후 모니터링 기술 실증(SS-URL; PBG$\mathrm{URL} /$ 처분환경 교란 예상 현안과제)

- 건설 중 지하부지환경 자료관리, 최종 성능 - 안전성평 가 및 운영허가 신청

- 운영 및 폐쇄단계

- 운영 전 성능 - 안전성 심사(규제기관) 및 운영허가

- 최종처분장 운영 및 처분장부지 주변지역에 대한 환 경감시관리

- 밀봉 및 폐쇄 후 모니터링 기술 실증
- 처분장 폐쇄 및 폐쇄 후 환경감시관리(필요시)

\subsection{2 규제 측면}

최종처분사업의 안전성을 확인하고 후속 업무의 진행 여 부에 대한 제도적 안전장치로서 규제 기능의 역할은 객관성 과 신뢰성 있는 절차와 과정의 표출로 나타난다. 따라서 규 제 측면에서 볼 때, URL프로그램에 대한 시각은 사업자와 수 평적인 기술 수준 및 이해가 요구된다. 즉, 모든 자료 및 정보 의 공유와 취득과정, 분석 · 평가 방법 및 결과 등에 대한 공 감대 형성이 전제되어야 한다. 처분안전성에 대한 보장은 성 능기간 측면에서 볼 때, 언제-어디서-무엇을-왜-어떻게 등에 관하여 사안 별로 시공간적인 관점에서 다양한 이해당사자 들이 공감할 수 있는 객관성과 신뢰성이 보장되어야 함을 의 미한다. 따라서, 가능한 한 다양하고 많은 처분시스템의 성 능 및 안전성 관련한 safety case를 필요로 한다. 이를 위해서 URL 프로그램은 사업자-규제기관의 사고와 이해 범위를 공 유하고 수용하는 핵심 역할을 가능하게 한다. 사업자의 URL 프로그램과 별도로 규제기관에서 자체적인 URL 시설을 구축 하여 실제 실증시험을 수행하는 사례도 있다 (Tournemier's URF-IRSN, 프랑스). 그리고 사업자로 하여금 URL 프로그램 을 후기단계에서 SS-URL로 개발하기를 요구한 사례도 있다 (RCF-UK).

\section{2 .3 국민이해 측면}

일반 대중은 사용후핵연료, 방사성폐기물, 심층처분, 처 분환경 및 지하지질 등의 용어에 익숙하지 않을 뿐만 아니라, 다양한 경로를 통해서 이와 관련한 긍정 혹은 부정적인 정보 를 단편적으로, 그리고 무방비로 접하게 된다. 원자력의 평 화적 이용의 성공적 구현을 위한 원동력은 다양한 이해당사 자들 간의 정보와 지식의 공유를 통해서 공감대 형성이 근본 적으로 전제되어야 한다. 하지만 선진국들에서 공통적으로 확인되는 사회적 측면에서 걱정꺼리는 기술적타당성과 안전 성 요건에 관한 한 심층처분의 적용에 대한 한계성과 직결된 다. 각국의 경험들을 토대로 국민이해(public acceptance) 와 정치적이해(political acceptance)에 영향을 미치는 요소 들은 기술적(technical), 구조적(structural), 절차상(process) 및 행동유형(behavioral) 측면 등 네 가지 요소에 의해 영향 을 미치는 것으로 정리한 바 있다[12]. 이들 요소들은 시간 경 과에 따라서 상호 연동되어 작용함으로써 다양한 이해당사 자들로 구성되는 개인 및 집단에 영향을 미치게 된다. 폐기 물관리와 관련하여 선진국들의 일반적인 사고로서, 공공의 참여와 투명성 제고 수준의 증대를 통하여 보다 효과적이고 
Dae-seok Bae. et al : Preliminary Review on Function, Needs and Approach of Underground Research Laboratory for Deep Geological Disposal of Spent Nuclear Fuel in Korea

효율적인 의사결정 과정에 도달할 수 있다는 생각이 광범위 하게 형성되어 있다는 것이다.

그런 의미에서 URL프로그램을 통하여 전술한 네 가지 요 소 간에 상호 연동되어 표출할 수 있는 기능과 역할을 기대 할 수 있다. 초기단계에서는 지하 심부의 지질환경에 대한 궁 금증을 해소하고, 처분장 설계와 안전성평가 과정에서 과학 이 어떻게 적용되고 있는지를 보여 줘야 한다. 중기 단계 이 후부터는 개발된 처분개념이 장기간에 걸쳐 과학적으로 안 전하다는 것을 입증해야 한다. URL 프로그램은 심층처분에 대한 방법과 기술을 제시를 통하여 안전성 입증 행위는 가장 실질적인 접근 방법일 뿐만 아니라 대중의 이해 증진을 위한 좋은 도구가 될 수 있다.

\section{URL의 필요성}

\section{1 해외 사례와 교훈}

고준위폐기물의 심층처분 관련 선진국의 경우 자국 내 분포하는 대표적인 선호암종 분포지역에서 URL을 이용한 자국 고유의 처분시스템의 성능 - 안전성을 입증하고 이를 바탕으로 처분시설의 부지선정 및 최종 처분장 후보부지의 특성평가 단계로 진입하였다 (Table 1; Fig. 1). 전반적으로
처분사업을 업무의 성격상 크게 준비단계와 상용사업단계로 구분할 수 있으며 두 단계는 서로 중첩되어 병행 추진하는 특 성을 보인다(Fig. 2). 준비단계는 처분시스템 확보 및 URL을 이용한 실증 - 시연 업무가 주요 업무이며, 본격적인 상용처 분사업의 시작은 준비단계 중/후반부 시기에 실증 - 시연과 전국 대상의 최종 처분장 후보부지를 결정하기 위한 선별평 가 및 선정업무와 중첩하여 수행된다. URL프로그램의 필요 성과 연계한 각국의 현황을 토대로 이를 요약하면 아래와 같 이 정리할 수 있다 $[5,11,12]$ :

초기 폐광산 중심의 G-URL로부터 신규 지역에 PBG-URL 계획으로 전환, 추진

고준위폐기물 처분연구와 관련하여 초기 단계에서 URL 을 이용한 접근은 폐광 등 기존 지하공동 시설을 이용한 시 도였으나, 자국내 선호암종이 분포하는 신규지역에서 PBG$\mathrm{URL}$ 을 계획하고 자국 고유의 처분시스템에 대한 성능 - 안 전성의 실증으로 전환하였다(Table 1; Fig. 3).

독일은 1980년대 초반 Konrad 폐철광산을 이용하였으 나, 암염돔(salt dome)을 선호암종으로 정하고 Goreleben( 구서독) 지역에 URL을 확보하여 방향을 전환 · 추진하였다 [13]. 스웨덴은 결정질 심성암반 분포지역의 Stripa 폐광산 에서 처분환경과 공학적방벽에 대한 연구를 시작하였다[14]. 하지만 처분시스템의 성능 - 안전성 입증을 위해 불교란 환

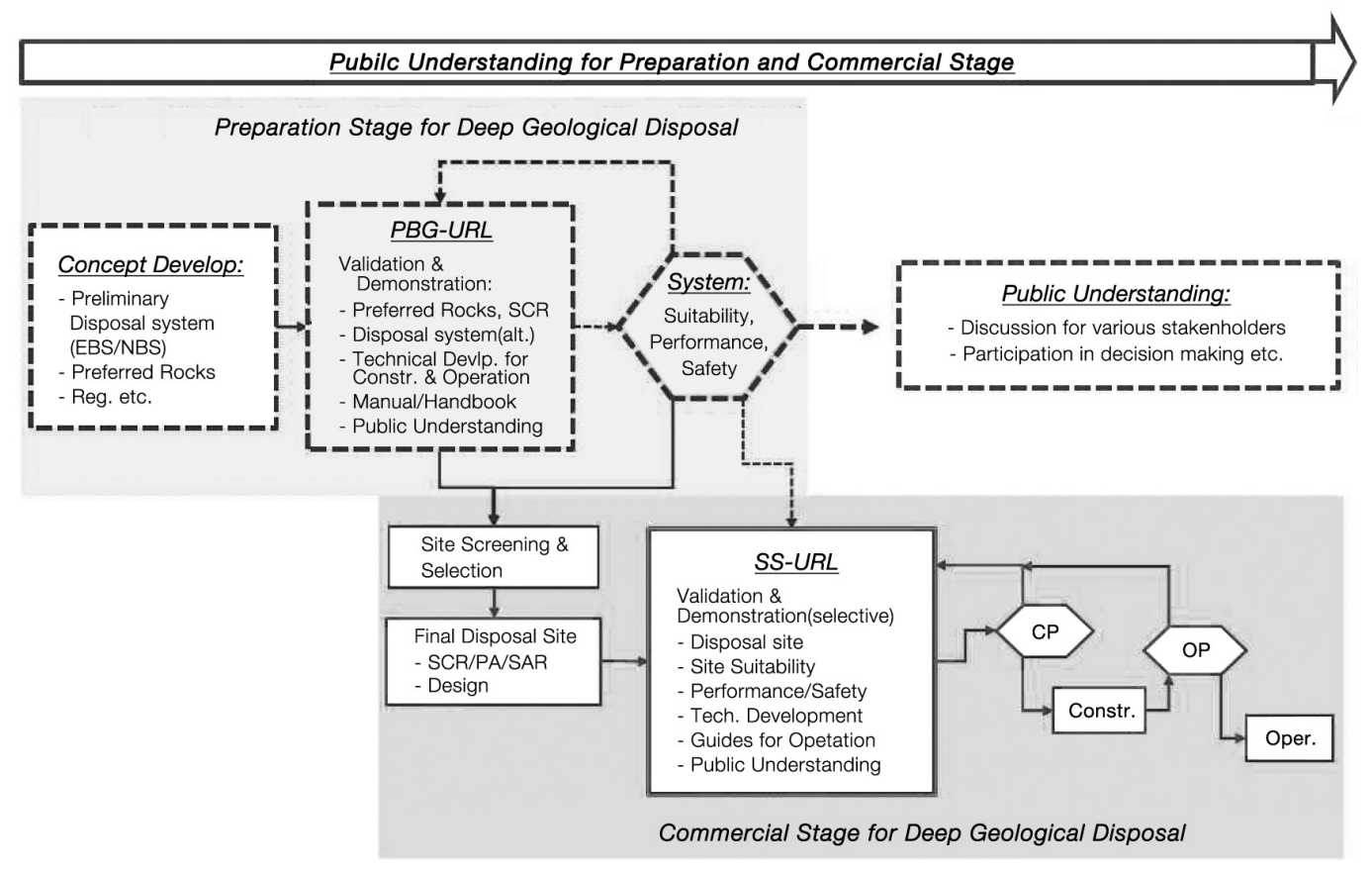

Fig. 1. Flow of commercial project for deep geological repository with URLs. 
Dae-seok Bae. et al : Preliminary Review on Function, Needs and Approach of Underground Research Laboratory for Deep Geological Disposal of Spent Nuclear Fuel in Korea

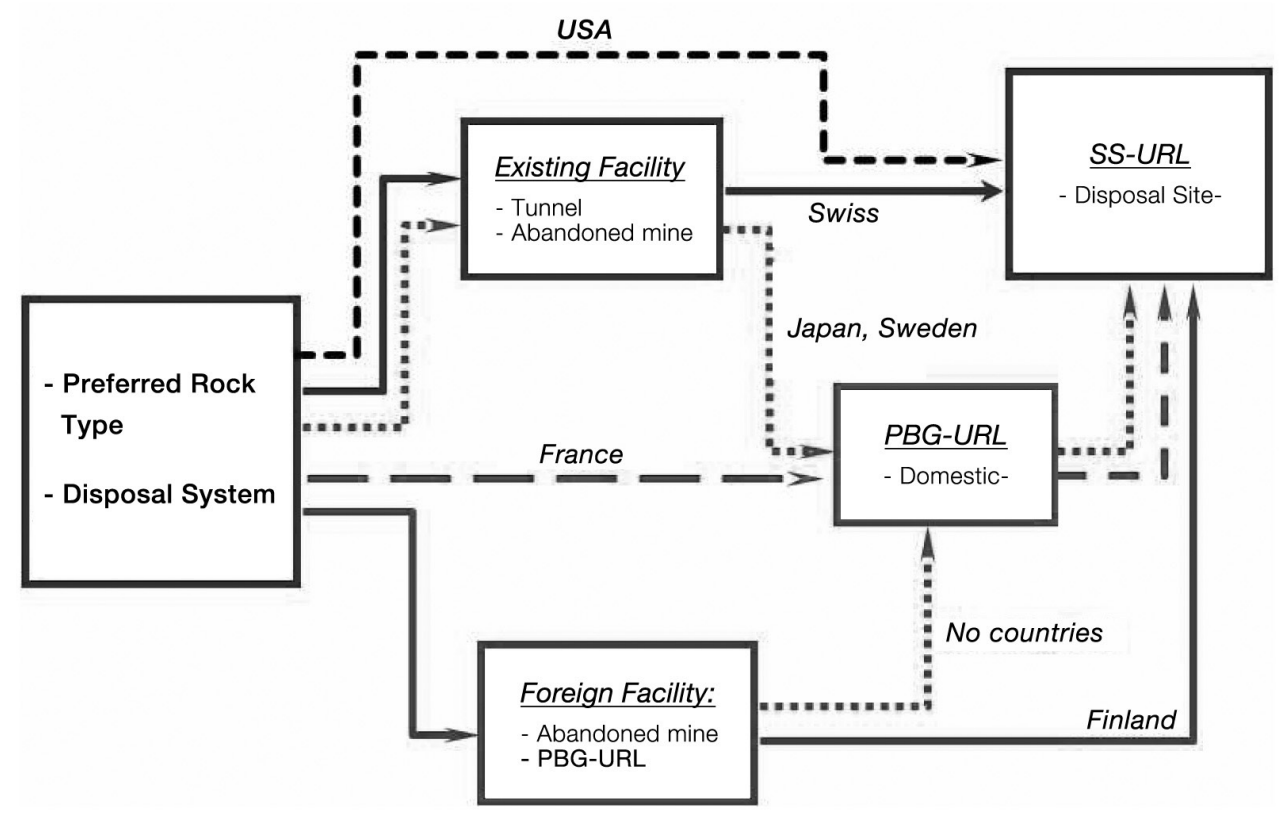

Fig. 2. Approach of a commercial disposal program by using various types of URLs.
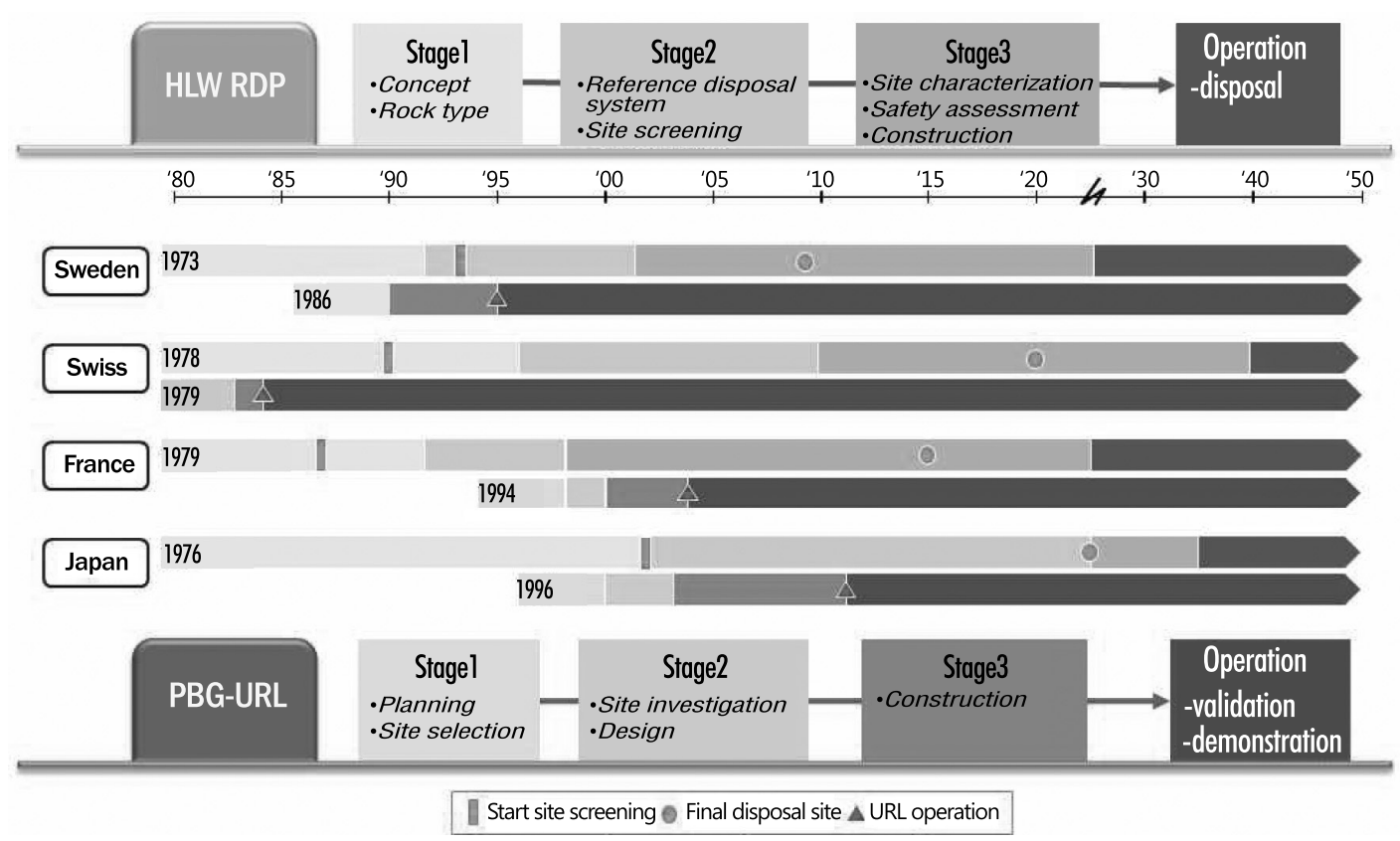

Fig. 3. Comparison between URL program and commercial disposal project over the world.

경의 확보가 가능한 Aspo HRL(PBG-URL)에서 다중방벽시 스템의 성능 · 안전성을 입증하는 실증시험과 건설·운영기 술 분야의 시연업무에 착수하여 현재 마무리단계에 진입하 였다[15, 16]. 핀란드의 경우는 처분모암이 화강암류로서 스
웨덴과 동일한 암종 · 처분시스템을 수용함으로써 모든 과정 과 결과를 공유하는 특별한 사례이다. 스위스는 기존 교통 터널 주변에 URL을 설치한 접근방법을 수용하였다. 일본은 Tono, Shobasama, kamaishi 등의 폐광산에서 지하지질환경 
Dae-seok Bae. et al : Preliminary Review on Function, Needs and Approach of Underground Research Laboratory for Deep Geological Disposal of Spent Nuclear Fuel in Korea

에 대한 특성 연구를 거쳐서, 화강암지역에 Mizunami URL 및 퇴적암지역에 Horonobe URL 등 두 개소에 PBG-URL을 각각 계획하고 현재 건설 중에 있다.

- 자국 고유의 선호암종을 선정하고 PBG-URL 추진

처분연구 수행 초기단계에는 다수의 암종에 대하여 검 토 및 연구를 수행하였으나, 최종적으로 1 2개 종류의 선호 암종으로 압축하여 집중함으로써 업무의 효율화를 도모하 였다. 대표적 선호암종의 결정은 천연방벽의 처분적합성에 대한 예비평가 대상을 압축 - 접근하는 측면과 함께 공학적 방벽의 성능확보를 위한 기술개발 및 실증업무의 범위와 항 목에 대한 경우의 수를 저감시키는 효과를 기대할 수 있다.

캐나다는 일찍이 캐나다 순상지의 화강암류를 결정하여, 가장 먼저 URL 관련 연구 및 실증을 수행한 바 있다. 스웨덴 과 핀란드는 동일한 처분대상 선호암종인 스카디나비아 순 상지 화강암류, 프랑스는 화강암과 점토암 등 두 개 암종에 대하여 집중하여 결과를 도출하여 현재에 이르고 있다[17, 18]. 독일 또한 다양한 암종에 대한 조사 - 평가를 시작하여, 최종적으로 암염돔이 상대적으로 보다 적절한 선호암종으로 평가하였다[19]. 한편 이들에 비해 비교적 후속 출발한 일본 은 아직 선호암종을 결정하지 않고 화강암과 퇴적암 등 두 개 암종에 대하여 가능성을 모두 열어 두고 계획 · 접근하는 방 식을 취하고 있다.

- 자국 고유처분시스템 개발 및 적용

고준위폐기물 심층처분시스템은 발전용 원자로와 마찬 가지로 다중방벽시스템 개념으로 접근한다. 차이점은 원자 로의 경우 다중방벽은 모두 공학적방벽 개념인데 비해서, 심 층처분시스템은 공학적방벽과 천연방벽 등 이질적인 방벽개 념으로 구성되는 다중방벽 개념이다[9, 20, 21, 22]. 이러한 요 구조건을 만족하는 심층처분시스템의 공학적방벽은 자국에 분포하는 처분대상 선호암종(천연방벽)에 대하여 조화로운 방벽시스템으로 수렴하여 요구 성능 - 안전성 요건을 만족하 도록 지속적으로 개선 · 보완되는, 이른바 “발명”개념의 접근 방법으로 이해된다. 이에 비해서 천연방벽은 새로운 물질이 나 장치를 개발하는 접근방법이 아니라 선호암종의 심부지 질환경에 대한 처분환경특성을 조사 · 규명하고 이의 처분적 합성을 평가 - 확인해 가는 접근 방법 즉, "발견"이라는 개념 으로 접근한다. 결국 심층처분사업은 "연구 · 기술개발 수행 방식으로 접근하는 상용사업”으로 이해하여야 할 것이다. 결 국 자국의 제반 환경여건에 적합한 고유처분시스템의 개발 -
적용은 필수 불가결한 사안이다.

- 자국 고유처분시스템의 성능 - 안전성의 실증 - 시연 프로 그램 시행

모든 분야에서 예외없이 신규 개발한 시스템은 상용화에 우선하여 실증시험 과정을 반드시 거쳐 안전성을 입증한 후 상용단계로 진입하게 된다. 특히 고준위폐기물 심층처분사 업은 각국 모두 처음 시도하는 사업이며, 반복적으로 대량생 산 방식의 사업이 아니다. 이와 같이 새로 개발 - 제안된 처분 시스템의 실증 과업은 성공적인 상용처분사업 수행에 앞서 반드시 거쳐야 하는 일련의 절차이다. 만약 최종처분장부지 의 SS-URL을 이용하여 실증 - 시연하고자 할 경우, 우선적으 로 최종 처분장부지가 결정되어야 한다. 고유처분시스템도 구축되지 않았거나, 성능 - 안전성이 입증되지 않은 처분시 스템으로 최종처분장 후보부지 선정업무에 임하게 되는 상 황이 전개된다. 이러한 접근방식으로 국민 공감대 확보를 기 대할 수 없을 뿐만 아니라, 제반 신뢰성 확보에 기약할 수 없 는 기간이 소요되는 시행-착오가 반복 또한 우려된다. 더욱 이 최종처분장에서는 처분환경의 교란을 최소화하여야 하므 로 처분시스템의 성능 - 안전성 입증을 위한 현안문제 해결 은 제한된 범위에 한 해서 허용될 수밖에 없다. 따라서 PBG$\mathrm{URL}$ 을 이용한 실증과정 - 시연을 통해서 SS-URL의 제한적 접근의 문제점을 해소하는 것이 바람직하다.

한편, 이미 성능 · 안전성 실증이 완료된 외국의 처분시 스템을 도입 및 적용할 경우, 번거로운 PBG-URL프로그램 과 정을 생략할 수도 있다는 의견이 당연히 제기되었다. 하지만 공학적방벽의 특성과 이와 직접적으로 연관되는 천연방벽특 성과의 연동성, 그리고 천연방벽 자체를 구성하는 자국내 선 호암종의 성능 및 안전성 요건이 동일한 경우에 한 하여 수용 가능할 것으로 판단된다. 스웨 덴-핀란드와 같이 특수한 경우 를 제외하고는 기대하기 어려울 것이다[6, 7, 10].

- URL 프로그램을 통한 천연방벽의 처분적합성 평가 및 성 능요건 확립

선호암종의 처분적합성 즉, 천연방벽의 성능인 핵종의 격리 및 이동 지연기능에 대한 평가와 정량적 성능요건이 요 구된다. 또한 이와 연동하는 공학적방벽의 보호기능과 성능 요건 역시 개발 - 제시되어야 한다. 이러한 기능의 평가는 지 질, 지질구조, 수리지질, 지구화학 및 암석역학 등의 부문에 대한 제반특성과 관련한 인자의 정량적 기술지침의 설정을 통해서 달성 가능하다. 이들 인자들은 처분안전성 확보를 위 
Dae-seok Bae. et al : Preliminary Review on Function, Needs and Approach of Underground Research Laboratory for Deep Geological Disposal of Spent Nuclear Fuel in Korea

한 충분요건(requirement)과 선호요건(preference) 등으로 분류하여 적용한다. 이들 요건들을 기준으로 처분장 후보부 지 선별 평가과정에서 요소-분야-인자에 따라 선택적으로 등 급을 조정하여 업무 수행단계 별로 그 적용 기준을 달리하 여 사용하였다. 따라서 이들 각각 인자들의 기준이 되는 세 부 부문별 해당 인자들의 정량적 처분적합성지표(suitability indicator)로 개발되어 이를 기준으로 탄력적 적용이 가능토 록 하였다. 이러한 기술지침으로서 개발 가능한 업무는 후보 부지 선정평가 업무에 적용 가능하도록 URL을 이용한 처분 환경특성에 대한 평가를 통해서 평가 - 정의된다[2, 23]. 또 한 이러한 정성 - 정량적 지표들은 규제기관의 안전성 심사 과정에 중요한 기술지침으로 반영 가능한 사례로 활용된다.

- PBG-URL 프로그램 수행과정 및 결과는 최종 처분장 후보 부지 선정업무에 활용

현재까지 사례로 볼 때, 최종 처분장부지 내 SS-URL에 서 처분시스템의 성능 - 안전성을 실증 - 시연하려는 계획 하 에 최종처분장 부지선정을 시도한 국가는 미국 외에는 확인 되지 않는다(Table 1, Fig. 2, 3). PBG-URL 프로그램의 다양 한 유형의 현안과제를 수행하는 과정과 결과를 통해서 최종 처분장후보부지 선정과정에 접목하는 이상적인 접근방식이 다[23, 24].

이와 같이, 반대의견을 가진 다양한 이해계층과의 순조 로운 대화와 긍정적인 분위기 조성과 국민이해 제고를 위해 서는 합리적이고 논리적이며 객관적인 접근방식이 유일한 대안이다. 자국 고유처분시스템의 성능 - 안전성에 대한 실 증 - 시연과 병행 혹은 후속과업으로 적정 시기에 최종처분 장 후보부지 선별 및 선정업무에 기여할 수 있도록 일정계획 을 수립·시행하는 것이 바람직하다.

\section{ص PBG-URL 부지는 최종 처분장부지가 아님}

실증시험용 URL부지선정 초기단계부터 이 부지를 최종 처분장 부지로 전환하려는 의도로 접근하고자 하는 경우, 제 반 규제측면 소위 "(가칭)방사성폐기물심층처분장위치에관 한기술기준”을 충분히 만족할 수 있어야 하다. 본 기술기준 을 모두 만족하는 후보부지 선별평가 기술지침이 준비되고 평가방법 등이 공감대를 통하여 확립되어 있어야 한다. 하지 만 스웨덴의 경우, 심층처분장부지의 위치에 관한 기술기준 을 근거로 URL시설의 위치를 결정하고, 건설 - 운영한 사례 는 확인된 바 없다[7]. 일본의 PBG-URL인 MIU시설은 "Toki city, Gifu prefecture" 지역사회/지방자치단체와 협력협정 내용에 URL 시설 내에 방사성핵종을 사용하는 연구행위는
없다는 것을 전제하였다.

- 건설 및 운영기술의 시연 및 종사자의 교육 훈련에 활용 최종처분시설 개발을 위한 고유처분시스템의 성능 - 안 전성 확보의 최대 관건은 건설 및 운영 기술의 실현 혹은 재 현 가능성이 보장되어야 한다. 즉 처분공에 캐니스터의 적치 와 완충재의 시공, 처분터널 내에 뒷채움재와 처분터널 밀봉 및 차폐벽체의 시공 및 성능에 대한 보장이다. 이와 함께 운 영기간 중 폐기물의 운반, 인수, 적치 및 감시 관리에 대한 구 체적인 시행 방안 및 결과에 대하여 확인 또는 실현 가능한 방법임을 확인할 수 있어야 한다. 또한 폐쇄후 안전성 확보 를 위해 필요한 경우 제도적 감시관리가 요구되는 상황이 발 생할 수도 있다.

전술한 일련의 성능 · 안전성 확보를 위한 시설개발 관 련 모든 업무는 전문기술자 등 종사자들의 업무 시행을 통해 서 이루어진다. 더욱이 이 모든 행위들은 자국 내에서 최초 로 시행하는 기술업무일 뿐만 아니라, 유일한 과업이 될 것 이다. 따라서 실제 처분장과 동일한 혹은 유사한 환경에서 잘 훈련되고 숙련된 전문기술자들의 확보·유지는 곧, 최종처 분시설의 안전한 건설 및 운영을 위해 필수 불가결한 과제이 다. 이러한 전반적인 과정과 절차에 대한 시행-착오를 철저 히 배격하고 객관적인 측면에서 예측 가능할 정도의 신뢰 구 축이 최선 방안이다.

- 최종처분장 안전성확보를 위한 safety case 개발 및 건설 허가 심사에 기여

고준위폐기물 심층처분시스템의 성능 · 안전성 입증방 법에 대한 국제적인 관심 사안은 건설 허가 심사과정에서 가 능한 한 다양하고 많은 경우의 안전사례를 개발 - 확보하여 제공하는 것이다. 심층처분시스템의 안전사례는 안전성 입 증을 위해 수반되는 모든 조사, 설계, 분석, 해석, 평가, 건설 및 운영에 이르기 까지 적용되는 기술과 결과들은 과거의 판 례(dossier, case)에 관한 내용이다. 일반적으로 이들 판례( 사례)는 특정 현안 및 사건에 대하여 적용 사례가 희박하거 나 없는 새로운 사안에 대하여 결정을 내려야 할 경우 매우 유용하게 적용 가능한 사례로 활용할 수 있다[25, 26, 27]. 따 라서 URL시설을 이용하여 실제 처분장과 유사한 환경조건 하에서 다양한 규모 및 유형의 safety case를 개발해 제시함 으로써 건설허가 신청 전에 일부 항목/부문에 대한 안전성 입증을 가능하게 할 수 있는 확실한 대안이다.

- 규제기관의 이해제고에 기여함으로써, 모든 정보와 이해 를 사업자와 공유할 수 있는 유일한 수단 
처분적합성과 성능 - 안전성 관련 기술적 요건들은 실제 로 검증 혹은 시험을 통해서 확인하는 데는 한계가 있을 뿐 만 아니라, 극히 제한적이다. 규제측면에서 볼 때, 건설허가 심사과정에서 불확실성의 저감과 안전성에 대한 신뢰는 상 용처분사업의 성패를 좌우하는 결정적인 역할과 기능을 한 다. 따라서 다양한 이해당사자들을 포함한, 규제기관과 사업 자는 수평적인 기술 수준으로 모든 부문의 현안에 대하여 이 해를 함께하여야 한다.

$\mathrm{URL}$ 시설을 이용한 실증 - 시연업무와 그 결과는 규제 차 원의 심사 - 평가 과정에서 직간접적으로 큰 신뢰감 및 자신 감을 제공하는 기회가 될 것이다. 제도적 보완이 될 경우, 직 접 실증 - 시연 과정에 다양한 형식으로 참여할 수 있는 기회 를 갖게 되는 것이다. 한편 전술한 바와 같이 규제기관이 직 접 URL프로그램을 수행한 경우도 있으며, 인허가 절차 및 심사 과정의 일부로 시험 및 시연(Test and Demonstration: T\&D)을 요구할 가능성도 있다 $[5,11,28]$.

- PBG-URL과 SS-URL 프로그램 간 실증 - 시연 현안과제의 선택적 수행

PBG-URL에서 고유처분시스템의 실증 - 시연 현안과제 에 대하여, SS-URL에서 선택적으로 선별 시행이 가능하다. 이는 PBG-URL 과업의 가장 큰 기대효과 중의 하나로 중요 한 의미를 가지며, 부지특성과 직접적으로 영향 관계가 없는 일부 현안 항목에 대하여 사전 안전성 입증 결과를 제도적으 로 수용하는 조치로 이해할 수 있다. 즉 처분시스템에 대한 성능 - 안전성의 실증 - 시연을 통해서 처분시스템을 인증하 는 계기를 마련함으로써, SS-URL에서 중복 투자를 축소하 고 기술적, 인문사회적 및 경제적 효과를 모두 기대할 수 있 게 하는 것이다.

핀란드의 경우, Aspo HRL과 Onkalo URL은 각각 PBGURL 및 SS-URL은 연구용과 상용 URL 사이의 선-후 수행현 황을 분명하게 비교, 확인 할 수 있는 대표적인 사례이다[10, $29,30]$.

- PBG-URL 주변지역의 환경영향 관련 연구에 지역사회 전 문연구기관의 참여 · 수행

주변지역 소재 학-연-산 등 관련 전문기관(local expert) 이 주축이 되어 PBG-URL시설의 건설 · 운영 중, 환경영향의 감시관리프로그램을 수립하여 공동/독립적으로 수행함으로 써 업무의 수행 과정 및 결과에 대한 공신력과 신뢰도 확보에 주력하였다. 대표적인 사례로서 $\mathrm{NoVa} \mathrm{FoU}$ 프로그램은 지역
사회 여러 대학과 산업체 및 기타 전문연구기관들과 SKB가 공동 추진하는 프로그램으로서, Aspo 주변지역의 정보를 공 유하고 이를 토대로 주변지역의 장기환경감시 프로그램으로 서 SKB가 재정지원을 담당하고 있다[31].

- 다양한 현안과제를 중심으로 국제협력 프로그램 시행 현재 국제협력 또는 공동 연구를 가장 활발히 수행하고 있는 Aspo HRL 및 Grimsell은 지질환경특성평가, 공학적방 벽, 천연방벽 및 건설기술 등의 분야에 걸쳐서 다양한 현안 과제에 대하여 실증 - 시연 연구를 수행하고 있다. 연구 활동 을 통하여 결과 및 기술 정보 교류 등에 집중적으로 참여하 고 있다[31]. 또한 IAEA의 주관으로 URF network이 구축되 어 자국 소재 지하연구시설 관련 업무들이 기관/국가 단위로 연계되어 공동/협력연구 체제를 유지하고 있다. PBG-URL에 서 국제공동/협력 연구를 통한 과정과 결과는 다양한 이해계 층에 대하여 처분안전성에 관한 신뢰도 제고에도 도움이 될 뿐만 아니라, 규체 차원에서도 처분안전성에 관한 이해제고 에 크게 기여할 수 있는 계기가 된다.

\section{a 대국민 이해제고 등 홍보 분야에 효율적 활용}

처분과 관련한 모든 업무들의 신뢰도 확보는 다양한 이 해계층이 직접 눈으로 보고 피부로 느낄 수 있는 방법으로 언 제 - 어디서나 확인 가능하여야 한다. 실제로 URL프로그램 의 근본적인 목적은 다양한 이해당사자들의 이해제고와 토 론과 대화의 마당을 제공하는 데 있다. URL 시설 및 관련 연 구시설과 관련한 모든 궁금한 사안들에 대하여 언제, 어디서 나 확인이 가능하도록 조치하였으며, 또한 원하는 시기와 형 식을 정하여 방문 홍보 및 교육 프로그램을 수행하였다[31].

이와 같이 선진국의 PBG-URL과업은 상용처분사업에 실 질적으로 큰 기여를 한 사실은 쉽게 확인 가능하다. 처분시 스템의 성능 - 안전성에 대한 입증과 관련한 모든 현안 과제 는 배경 및 필요성 분석을 통해서 목적과 목표를 설정하고 세부 수행 내용을 발굴하여 단계적으로 체계적인 수행 프로 그램을 구축하였다. 실증·시연 대상 현안과제들은 선호암 종과 고유 처분시스템과의 상호연계성을 감안하여 발굴 및 제시되었다. 연차별 수행 결과에 따라 육하원칙에 의거하여 정기적으로 추진 실적과 결과 및 평가를 통해서 신규 현안과 제의 제기 및 보완 등의 차기 단계 수행 방안에 대한 계획을 재조정하였다.

\section{2 국내 $\mathrm{PBG}-\mathrm{URL}$ 시설의 필요성}


Dae-seok Bae. et al : Preliminary Review on Function, Needs and Approach of Underground Research Laboratory for Deep Geological Disposal of Spent Nuclear Fuel in Korea

\subsection{1 개요}

URL 과업수행계획 입안 초기단계에서 수행개념을 확립 하는데 전략적 측면에서 수반되어야 하는 아래의 현안 사안 들과 해외사례들을 근간으로 접근한다[5]:

- PBG-URL이 필요성 여부에 대한 의사결정을 어떻게 할 것인가.

- PBG-URL 부지의 암종은 무엇을, 어떻게, 언제 결정 하여야 하는가.

- 어떤 유형의 URL이 필요한가:

- PBG-URL 사업계획을 언제까지 계속할 것인가.

- URL 이용의 기대효과는 무엇인가.

\subsection{2 우리나라의 $\mathrm{PBG}-\mathrm{URL}$ 프로그램 필요성}

전술한 PBG-URL 과업의 수행 필요성 부문과 관련이 있 는 선진국들의 그동안의 수행 실적을 통하여, 향후 우리나라 에서 적용 가능한 PBG-URL 과업의 수행 필요성을 요약 - 정 리하였다.

- 국내 PBG-URL 필요성

- 고유처분시스템의 성능 · 안전성은 PBG-URL에서 입 증한 후, 최종처분장 건설허가에 적용 가능하며 지속 적으로 성능 - 안전성에 대한 신뢰성을 제고하여야 함 (Fig. 1).

- 자국 선호암종의 처분적합성 입증 및 적합성지표 개발 은 PBG-URL에서 완성되어야 함

- PBG-URL에서 성능 - 안전성이 입증된 처분시스템은 SS-URL에서 일부 현안과제에 국한하여 실증함으로써, 재실증/중복실증의 부담을 충분히 저감할 수 있음.

- PBG-URL에서 건설 · 운영 전문 인력의 교육 · 훈련은 처분안전성 확보를 위한 가장 근본적이고 기초적인 업 무임.

- 처분안전성확보를 위해 PBG-URL시설을 이용한 safety case 개발 - 확보는 필수 사항임.

- 후보부지선정 등 상용처분사업 전반에 걸쳐 다양한 이 해계층의 이해제고에 필수적임.

- PBG-URL시설은 자국 고유의 선호암종 분포지역에 입 지하여야 함.

- 폐광산 등 기존의 지하공간 시설을 이용한 실증·시 연 과정과 결과에 대한 신뢰성과 효율성은 기대하기 어려움.

무엇보다 중요한 핵심 사안은 자국 고유처분시스템의 성
능·안전성에 대한 입증과정(실증·시연)은 반드시 거쳐야 하는 절차로 이해하여야 한다. 상용처분사업의 효율적인 추 진을 위해 다양한 이해계층의 의견수렴을 통한 공론화와 대 화 - 토론의 도구로 매우 효과적임과 동시에 신뢰성확보 수 단으로 필수 불가결한 과정이다. 한편, 예상 인문 · 사회적, 기술적 및 경제적 측면에서 선결하여야 할 주요 현안문제를 정리하였다:

- 상용처분사업 수행을 위해 확립되어야 할 전제조건

- $\mathrm{SF}$ 국가관리기본계획 수립

- $\mathrm{SF}$ 최종처분사업기본계획 수립 및 제도 정비

- 국내외 심층처분 관련 제반 여건을 고려한 국내 적용 규제 관련 기술 요건 확립

- 국내 분포하는 대표적인 암종을 토대로 처분대상 선호 암종의 평가 및 선정

- 자국의 고유처분시스템을 개발 및 확보

- 심층처분장 건설 · 운영 기술 - 장비 개발 및 이의 검증 과 시연은 필수

특히 최종처분장 후보부지 선정업무 수행에 선행하거나 혹은 병행함으로써 국민 공론화를 통한 공감대 구축 과정에 중심적인 역할을 할 수 있다.

\section{4. $\mathrm{PBG}-\mathrm{URL}$ 프로그램 추진방안 검토}

\section{1 기본 방향}

전술한 고유처분시스템의 성능·안전성 입증을 휘한 PBG-URL의 필요성을 바탕으로, 자국 실정에 적정한 PBGURL프로그램을 구축에 선행하여 준비해야 할 현안문제는:

- 심층처분과 관련한 안전성 학보를 위한 제반 국내외 규 제관련 기술기준/지침의 정비

- 처분대상 선호암종의 평가 및 결정

- 성능 · 안전성 실증용 자국 고유처분시스템의 개발 및 구축

등의 확립과 함께 적정 착수 시기 · 일정 계획을 수립하 여야 할 것이다.

\section{2 분야 및 부문별 요건 검토}

사용후핵연료 처분업무를 착수하기 전에 모든 관련 제반 
Dae-seok Bae. et al : Preliminary Review on Function, Needs and Approach of Underground Research Laboratory for Deep Geological Disposal of Spent Nuclear Fuel in Korea

규정 및 기준이나 지침들과 관련한 사업수행 기술지침은 사 전에 준비 및 결정되어야 한다. 이를 토대로 처분사업자 측 면에서 확보 및 확립하여야 할 적용 기술 기준 및 지침들은 각 분야 및 추진 단계 별로 다양하게 요구된다. 한편, 사용후 핵연료 최종처분장의 안전성확보를 위한 처분장 지질환경의 기본적인 요건에 대하여 정리한 바 있다[4]. 하지만 이들 요 건과 연계하여 처분사업자가 준비해야 하는 정량적 처분적 합성지표 인자에 대한 세부적인 지표들은 외국의 적용 사례 들을 직접 반영할 수는 없다. 따라서, 규제측면과 사업자 입 장에서 상용 처분사업에 적용을 위한 각 부문별 특성에 적합 하고 보다 정량적이고 구체적인 처분장부지 적합성지표에 관한 기술지침으로 확대 개발되어야 할 것이다. 이러한 기술 기준/지침들은 PBG-URL 및/혹은 안전사례 작성 등을 이용 한 우리나라에 적합한 고유의 적정 처분장 지질환경특성에 대한 정의(type environment)를 확립하여야 한다.

이러한 일련의 업무들은 사업자가 먼저 현안문제를 도출 하고 의견 및 해결 방안에 대하여 다양한 이해당사자들과 논 의를 통해서 관련 기술기준과 지침들을 정립할 수 있도록 추 진하는 것이 바람직하다. 한편 국내의 경우, "고준위방사성폐 기물심층처분시설에관한일반기준(안)"이 제안되어 현재 의견 수렴 중에 있다[32]. 이 규정은 고준위폐기물처분 규제기반 구 축 및 IAEA 폐기물안전협약 이행과 국내 심층처분시스템 및 선진핵주기 개발에 필요한 기술기준을 제공하고, 국내 고준위 폐기물 처분시스템 안전성검증의 필요성을 기반으로, 심층처 분시설 관계규정 시행과 처분안전성 확보에 필요한 기술기준 수립하기 위하여 준비되었다.

현재 국내의 심층처분사업과 관련한 제도적 준비 업무들 이 서서히 시작한 것으로 이해된다. 현 단계에서 이와 병행하 여 또한 전술한 고시(안)과 연계하여 사업자로서 준비 현안 과제로서 필요한 세부 요소들에 대하여 관련 기술지침 등 기 술현황들에 대한 구축이 수반되어야 할 것이다.

\section{3 처분 선호암종}

처분장이 위치하는 기반암(모암)은 천연방벽 성능기간 을 유지하기 위해서 근본적인 방벽성능이 규명 및 정의되어 야 한다. 천연방벽으로서 지질환경의 다양한 기능을 규명하 고 확인한 후 이에 대한 검 · 실증과정을 거침으로써 천연방 벽의 성능은 확보될 것이다. 다시 말하면 천연방벽의 성능은 다양하고 복합적으로 연동하여 나타나는 자연환경의 현상 특성이 공학적방벽을 보호하고, 방사성폐기물을 격리 및 지 연시킬 수 있는 능력을 밝히고 확인함으로써 방벽 성능을 확
보하게 되는 것이다.

따라서 처분모암의 선정은 자국의 지질학적 특성을 가장 잘 반영할 수 있는 대표적인 분포암종으로 선정하여야 한다. 이와 동시에 전술한 규제요건을 고려한 적정 처분환경이 되 어야 하며, 모든 관련 분야 · 부문에 대한 정밀하고 장기적인 입증과정을 거친 후에 천연방벽의 성능 · 안전성 요건이 정 의 · 확립될 수 있을 것이다. 하지만 자국 내에 분포하는 모 든 암종을 대상으로 최종적으로 요구되는 성능 - 안전성 관 련 모든 요소-분야-인자에 대하여 조사 · 분석 · 평가에 의해 선호암종을 결정하는 방법은 비효율적이다. 자국 내 분포하 는 암종의 특성을 토대로 단계적인 검토과정을 거쳐 국내 실 정에 가장 부합되는 다수(2 3개 이하)의 대표 암종을 선호 암종으로 압축하고, 처분적합성에 대한 평가를 통하여 적정 기능을 정량화 · 정의하는 것이 바람직하다.

\section{4 고유처분시스템 구축}

처분사업 수행에서 기술적측면의 핵심은 성능 - 안전성 이 입증된 고유처분시스템의 확보이며, PBG-URL의 기능은 확보된 고유처분시스템의 성능 - 안전성 입증을 위한 실증 시연 기능이다. 현재 국내외적으로 다양한 유형의 처분시스 템이 개발 - 제시된 바 있다. 한편 국내 역시 고준위폐기물 심 층처분시스템에 대한 기본개념 설정 수준의 기준처분시스템 (KRS: Korea Repository System)를 제시하고 IAEA의 peer review 과정을 거친 바 있다[33]. 따라서 우리나라의 경우, 처분사업 착수를 위해서는 현재 국내 여건을 감안하여 아래 와 같이 접근하는 것을 제안한다:

- 국내외 사례에 대한 정밀 분석 · 평가를 통하여 사업자 고유처분시스템 기본개념(초안: Ver.0)을 구축한 후

- 이를 기반으로 다중방벽 성능 · 안전성 요건, 설계, 건 설, 운영 및 폐쇄 등 전 과정에 대하여 미흡한 부문에 대한 수정·보완 과정을 거쳐, 실증·시연용 사업자 고유처분시스템(Ver.01: 실증용)을 확립한 후,

- PBG-URL시설에서, 제안된 시스템의 성능 · 안전성 실 증·시연과정을 거쳐 고유처분시스템(Ver. final: 상용 처분사업 적용용)을 완성하고,

- 병행하여 상용처분사업 적용을 위한 개별 현안 별 업 무수행 기술지침서 개발 · 확보

등을 통하여 후속 업무수행체계를 확립함으로써 최종 처 분시스템으로 자리매김하여야 할 것이다. 한편 이후 본격적 인 상용처분사업 단계에 진입 및 수행과정을 통해서 처분시 
Dae-seok Bae. et al : Preliminary Review on Function, Needs and Approach of Underground Research Laboratory for Deep Geological Disposal of Spent Nuclear Fuel in Korea

스템에 대하여 개선하여야 할 사항은 건설허가 신청 전까 지 지속적인 수정·보완과정을 통해서 최종 상용처분사업 에 적용 가능한 고유처분시스템으로 정립되어야 할 것으로 판단된다.

\section{5 세부현안과제 도출 및 $\mathrm{PBG}-\mathrm{URL}$ 프로그램 구축 방안}

\subsection{1 해외 $\mathrm{PBG}-\mathrm{URL}$ 의 주요 연구 현황과 성과}

전술한 바와 같이, RDP측면에서 PBG-URL의 역할은 곧 처분시스템의 성능 - 안전성 입증과 관련한 일련의 과정 및 결과에 대한 신뢰 구축과 전문기술을 증진시키는 것이다. 또 한 과학 - 기술자의 양성과 기술발전을 위한 훈련장으로 지속 적으로 활용되었음을 의미한다. 그러나 기술적인 현안과제들 을 해결하는 것이 최상의 목적은 아니며, 처분업무 이외의 다 양한 관련 분야가 참여하는 공동 프로젝트를 추진할 수도 있 다. 사업자는 항상 처분장개발 프로그램의 핵심 현안과제들 과 직면하기 때문에 처분개념에 대한 생각과 시험 등은 최첨 단 수준으로 추진되어야 한다. PBG-URL 시설에서 실증 연구 결과에 대하여 선진 외국의 사례를 중심으로 주요 분야 별로 정리하면 아래와 같다[34]:

- 심부지질특성 조사기술의 개발 - 비교 및 신뢰도 확 인 · 제고

- 심부지질환경에 대한 보다 많은 정보 획득을 위한 부 지특성조사 전략의 적용

- 핵종이동 현상에 대한 개념 및 수치모델 개발 및 실 증시험

- 굴착으로 인한 공동주변 암반의 영향 특성 정량화

- 지하 굴착기술 시험 및 개발

- 방사성폐기물 처분공내 적치로 인한 환경영향 모사

- 장기적 현상, 부식, 암반역학적 안정성 및 폐쇄후 현 상 등

- $\mathrm{EBS}$ 성능 실증·시연

- 대규모 처분공학기술 실증

이러한 성과와 함께 현재, URL을 이용한 선진 각국의 접 근 경향은 처분사업 시작 초기에 기본적인 타당성과 기초적 인 지질자료 축적의 중요성에 대한 관심으로부터 자국 고유 처분시스템 개발과 함께 실증시험과 기술시연 등의 분야로 전환해 나가는 추세에 있다. 즉 URL을 이용한 중간 및 후기 단계에 이르러 아래와 같은 분야에 비중을 두고 진행해 가 고 있다.

\subsection{2 국내 현안과제 도출}

PBG-URL프로그램은 가장 효율적이고 실현 가능한 방법 으로 불확실성을 해소 혹은 저감하도록 설계되어야 한다. 처 분장개발에 대하여 단계별 추진 방법을 위한 요구조건의 틀 내에서 수립되어야 할 필요가 있으며, 각 단계별 수행 결과 의 평가를 토대로 충분한 신뢰성이 확보된 후, 다음 단계로 진행되는 것이다. 선진 외국의 URL 및 처분시스템 성과를 모 두 우리나라의 실정에 적용할 수는 없다. 그 이유로, 첫째 나 라마다 처분대상 모암 또한 다양할 뿐만 아니라, 둘째 이로 인하여 당연히 고유처분시스템 또한 동일할 수 없다는 것이 다. 물론 적용 가능한 현안문제와 접근 과정과 결과를 선별 적으로 수용함으로써, 후발국가로서의 유리한 측면을 충분 히 활용하여야 효율적이고 성공적인 처분사업으로 이어질 것이다. 따라서 현재 여건 하에서 PBG-URL 시설에서 실증 시연 대상의 현안과제들에 대하여 적정 항목을 제안하기 위 해서 아래와 같은 측면을 고려하여 접근하여야 할 것이다:

- 우리나라 고유한 특성(규제기준-선호암종-처분개념 등)을 반영한 실증 - 시연 대상 항목

- 외국의 기존 실증·검증 - 시연 사례 중, 우리 고유처 분시스템에 직접 적용 가능한 항목 검토 및 반영

- 이외에 향후 국내 PBG-URL 및 SS-URL에서 실증 - 시 연 혹은 검증이 필요한 현안과제

여기서는, 선진 외국의 기 수행한 실증 - 시연 사례를 토 대로, 예상되는 현안과제 분야를 조사, 시험, 분석, 해석, 평 가 및 공학기술(건설 - 운영) 등 아래와 같이 별로 크게 10 개 분야로 분류, 제시하였다:

- 예비조사 방법 검증 분야 (Verification of Pre-investigation Methods)

- 지질과학 분야 (Geoscience)

- 천연방벽시스템 성능 · 안전성 분야 (Natural Barrier System)

- 공학적방벽시스템 성능 · 안전성 분야 (Engineered Barrier System)

- 건설 및 운영 기술 분야 (Engineering Techniques for Construction and Operation)

- 건설 및 운영 기계 - 장비 분야 (Engineering Mechanical Equipment)

- 환경연구 분야 (Environmental Research)

- 품질보증 분야 (Quality Assurance)

- 대국민홍보 분야 (Public Relation and Information Activities) 
Dae-seok Bae. et al : Preliminary Review on Function, Needs and Approach of Underground Research Laboratory for Deep Geological Disposal of Spent Nuclear Fuel in Korea

- 국제협력 분야 (International Cooperation)

각 분야 별 세부 현안과제들은 고유처분시스템 개발과정 및 완료 후 결과를 반영하여 다시 보완토록 하여야 할 것이 다. 자국 고유처분시스템의 성능 · 안전성에 대한 실증 · 시 연 프로그램의 구축을 위해서 주요 현안과제는 실증용 고유 처분시스템과 PBG-URL시설 대상부지 확보와 함께 조사, 시 험, 분석, 해석, 평가, 공학기술 등의 과정에서 수행할 연구 수행 항목들이다. 다만 자국의 여건에 접목하면서 차별화하 거나 중복성에도 불구하고 재수행하여야 할 필요성은 반드 시 근거를 확립되어야 할 것이다. 이러한 관점에서 후발국가 들은 선진국의 사례를 교훈으로 자국의 실정에 부합되는 독 창적인 URL 프로그램을 개발 및 적용하는 것이 바람직하다.

\section{URL 시설 확보 방안}

\subsection{URL 시설 유형 검토}

전술한 바와 같이, URL 사업계획 입안 단계에서 제일 먼 저 의견 수렴되어야 하는 현안은 "어떤 유형의 URL시설을 이 용하여 어떠한 방법으로 접근하여야 하는가" 이다. 대부분의 선진국들은 PBG-URL과 함께, SS-URL은 최종 처분장부지 내 에 필수적으로 설치 · 운영하여야 하는 제도적으로 규정하고 있는 시설이다[32].

따라서 G-URL, PBG-URL 및 SS-URL을 임의의 특정 방식 으로 조합 혹은 선정하여 처분시스템의 성능 - 안전성을 입 증할 것인가에 있어서, 아래와 같이 네 가지 유형의 접근 방 법을 예상할 수 있다(Fig. 2):

- SS-URL 만을 이용한 실증 · 시연

- $\mathrm{G}-\mathrm{URL} \rightarrow \mathrm{SS}-\mathrm{URL}$ 과정을 통한 실증 · 시연

- $\mathrm{PBG}-\mathrm{URL} \rightarrow \mathrm{SS}-\mathrm{URL}$ 과정을 통한 실증 · 시연

- $\mathrm{G}-\mathrm{URL} \rightarrow \mathrm{PBG}-\mathrm{URL} \rightarrow \mathrm{SS}-\mathrm{URL}$ 과정을 통한 실증 · 시 연

- SS-URL 만을 이용한 실증 · 시연

$\mathrm{URL}$ 시설을 최종 처분장부지에 한 개소만 건설 및 운영 하는 접근방법으로서, 이 접근방법의 최대 장점은 일정 단축 과 함께 “경제적 효율성 측면”에서 최대의 장점을 확보할 수 있다. 하지만 이를 위해서는 아래와 같은 전제 조건을 반드 시 해결하여야 가능하다:

- 반드시 최종 처분장부지가 미리 선정되어야 함

- 선정된 후보부지는 고유처분시스템의 성능 - 안전성
입증에 반드시 성공하여야 함

최종처분장 후보부지로 선정되기 위해 당면한 선해결 현 안과제는 선정 근거에 해당하는 안전성 측면에서 적용하여 야 하는 “적정처분장 부지요건의 정립 및 제시”함께 “지역주 민의 동의”이다. 또한 이 시점에서 적용되는 고유처분시스템 (안)은 이의 성능 - 안전성의 입증이 상당 수준에 도달한 상 태이어야 한다. 선진국의 사례로 볼 때, 후보부지 선정평가 를 위한 제반 기술지침들은 “처분적합성지표”(site suitability indicator)의 정립과 이를 기준으로 후보부지 선별 평가 단계 별 적용 정량적 기술기준의 탄력 적용 및 가중치를 결정하게 된다. 이러한 기준이 되는 다양한 분야-요소-인자 별 “처분적 합성지표" 중 상당 부분은 PBG-URL프로그램을 통해 처분시 스템의 실증 - 시연과정을 거쳐 정립되고 정의되는 것이다. 하지만 이러한 과정을 거치지 않은 상태에서 SS-URL을 이용 한 처분시스템의 성능 - 안전성의 입증을 시도한다는 것은 다 양한 이해당자들을 대상으로 공감대 형성에 장애가 불가피하 다. 더욱이 최종처분장 후보부지의 처분적합성 입증에 실패 할 경우, 새로운 후보부지선정과 SS-URL 건설 - 운영 등의 중 복 수행에 대한 부담은 불가피하다. 또한 SS-URL에서는 최종 처분장 부지내 예상 처분환경 영역에 대한 교란현상을 야기 하는 행위는 철저히 배제하여야 하므로 제한적인 내용과 범 위 내에서만 성능 · 안전성의 입증을 위한 실증 - 시연 행위가 가능할 뿐이다.

- G-URL $\rightarrow \mathrm{SS}-\mathrm{URL}$ 과정을 통한 실증 · 시연

일부 선발 국가에서 처분사업 초기 단계에서 접근한 유형 으로서 PBG-URL과 차별화한 G-URL의 특성은 대부분 기존 시설(폐광 혹은 교통/산업 터널)을 활용하는 방법이다. 일부 G-URL(Stripa, Grimsel, Mont Terri, Tono and Kamishi 등) 들은 기존의 지하공간 시설들을 이용해서 개발하였으며, 이 를 토대로 SS-URL 개발 시 고려해야 하는 일부 중요한 인자 들을 고려하지 않는다는 것을 이해하여야 한다[5]. 스위스의 GTS는 특수한 경우로서 엄밀한 의미에서 PBG-URL로 간주 하여야 할 것이다(Fig. 2).

- $\mathrm{PBG}-\mathrm{URL} \rightarrow \mathrm{SS}-\mathrm{URL}$ 과정을 통한 실증 - 시연

고유처분시스템의 성능 · 안전성에 대한 실증·시연과 정을 거쳐서 최종 처분장개발에 임할 수 있는 가장 이상적 인 접근 방법이다. 대부분의 선진국들은 가능한 한 교란되지 않은 심부지질환경의 PBG-URL에서 처분시스템의 성능 · 안 전성에 대한 실증 - 시연을 통한 고유처분시스템을 확보하는 방식으로 전환 또는 수행 중에 있다. 이 과정에서 기술적 목 
Dae-seok Bae. et al : Preliminary Review on Function, Needs and Approach of Underground Research Laboratory for Deep Geological Disposal of Spent Nuclear Fuel in Korea

표 달성과 병행하여 다양한 이해계층을 위한 국민이해 제고 과업을 병행하는 것이 성공적인 처분사업 목표를 위한 지혜 임을 명심하여야 할 것이다.

PBG-URL 개발프로그램이 SS-URL 개발과정에서 수반되 는 가정들에 대한 광범위한 기초자료가 된다면, 그 유용성 은 보다 크게 기대할 수 있다. 이와 같이 PBG-URL프로그램 은 SS-URL에서 제한적인 조건으로 인해 수행이 어려운 현안 과제에 대한 해결책으로 의미를 부여할 수 있다. 우리나라 와 같은 후발국가의 입장에서 볼 때, $\mathrm{PBG-URL} \rightarrow \mathrm{SS}-\mathrm{URL}$ 과정을 통한 실증 - 시연 방법이 가장 바람직한 것으로 사료 된다(Fig. 2).

- G-URL $\rightarrow$ PBG-URL $\rightarrow$ SS-URL 과정을 통한 실증 - 시연 이 과정은 초기 선발 선진국들이 폐광에서 시험적 처분 관련 연구를 시작하여 전술한 “3)"항의 접근 방법으로 전환 함으로써, 모든 방법을 거쳐 수행한 경우이다. 이는 선발 추 진한 개척자들이 감수하여야 하는 시행-착오의 하나이며 불 가피한 경우라고 판단된다. 하지만 대부분의 심층처분프로 그램을 추진하였거나 수행중인 국가들은 불가항력적으로 이 접근 방법의 절차를 거치는 것으로 판단된다.

전술한 바와 같이 PBG-URL의 필요성에 관한 한 경제적 인 측면은 논의의 대상이 아님을 이해하여야 할 것이다. 한편 URL의 유형과 암종 별 관계에서 뚜렷한 상관성은 확인되지 않으며, 암종에 따른 URL의 유형 비교는 큰 의미가 없는 것 으로 판단된다. 다만 자국의 선호암종에 대한 결정이 선행되 어야 하며, 이 암종 분포지역에서 신규 부지를 확보하여 접근 하는 방법이 일반적이다. 우리나라에서 대부분 사용 종료된 교통터널들은 지상 피복 심도가 얕으며, 일부 철도터널 중 백 두대간을 관통하는 경우를 상정할 수 있으나 대부분 탄전이 나 석회암지대에 분포하여, GTS와 같은 수준의 URL로 활용 가능성은 거의 기대할 수 없다. 이외에 과거 지하 수 백 미터 규모의 채굴적을 가지는 폐광산이 다수 존재하지만, 이들 역 시 전술한 폐광산의 단점에서와 같이 비현실적이다.

\section{2 부지요건 검토}

PBG-URL 부지요건은 처분장(처분공-처분터널 등)의 근 계 혹은 근계-원계 점이지역 등의 처분환경에 대한 처분적 합성 요건(충분 혹은 선호요건)에 관련 사항 중에서 일부 항 목을 중심으로 반영하는 것이 바람직하다. 이는 최종처분장 부지의 SS-URL과 차별하여 PBG-URL부지가 실제 최종처분 장부지가 아니기 때문에, 원계영역의 요건 중 장기지질안정
성 등과 관련한 요건의 반영 가중치는 매우 낮다. 일부 선발 국가에서는 기존 원자력산업시설 주변지역 혹은 특정 요건 만 고려하여 자연환경 보호 전제 하에서 토지이용계획을 수 립하였다.

PBG-URL 부지요건의 검토에 앞서 전술한 모든 특성들을 토대로 정리하면, 우선 "URL시설부지는 최종처분장 부지가 아니다”라는 대명제이다. 우리나라의 경우 아직 규제 기준들 이 제정 - 공포되지 않았으므로, IAEA에서 권고하는 10 개 항 의 처분장부지요건을 토대로 특정 항목을 중심으로 부지요건 에 관한 지침으로 수용하는 것이 바람직하다[35]. 따라서 아 래와 같이 크게 3 개 등급(적극 반영; 반영; 참고 및 미반영) 등 으로 분류하여 접근하는 것이 바람직하다:

- 중점 반영 부문: 지침 1 (지질계통); 지침 8(환경보호) 과 지침 9 (토지이용)

- 탄력적 반영 부문: 지침 3(수리지질) 및 지침 4(지구화 학), 10 (사회적 영향) 및 지침 11 (기타 조건)

- 참고 혹은 미반영 부문: 지침 2(자연환경의 장기적 변 화), 지침 5(인위적사건), 지침 6(건설 및 공학적 조건), 지침 7(폐기물운반)

이와 같이 PBG-URL 부지요건에서 주요 핵심사항은 암 종이며, 대규모 암반을 대상으로 적절한 지질구조가 분포하 고, 업무효율성 등에 비중을 두고 결정하는 것이 바람직할 것 으로 판단된다. 즉:

- 국내 분포암종 중 대표 선호암종 분포지역을 중심으로 충분한 분포면적과

- 토지이용 계획 측면에서 양호한 조건을 가지며

- PBG-URL시설의 건설 · 운영으로 인한 주변지역의 환 경영향을 최소화하고

- PBG-URL시설의 건설 및 운영 측면에서 접근성 등 효 율적인 활용도가 높고

- 지역사회에서 호응도가 높은 지역

등의 조건을 갖는 지역으로서 최종 처분장 후보부지 선 정시 적용 예상되는 기술지침에 비해서 훨씬 단순한 부지조 건과 절차를 정하여 접근하는 것이 타당하다. 즉 일반적인 산업시설이나 신규 광산개발과 같은 지역개발 차원에서 접 근하는 것이 이상적이다.

\section{$5.3 \mathrm{PBG}-\mathrm{URL}$ 프로그램의 적정 수행 시기 검토}

\subsection{1 해외사례}


Dae-seok Bae. et al : Preliminary Review on Function, Needs and Approach of Underground Research Laboratory for Deep Geological Disposal of Spent Nuclear Fuel in Korea

선진국의 PBG-URL프로그램이 상용처분사업에 실질적 으로 어떠한 기여를 한 것인지에 대한 사례와 교훈를 토대로 적절한 수행시기와 목표 일정에 대한 비교 분석이 선행되어 야 할 것이다[34]. PBG-URL을 이용한 실증 - 시연과업의 착 수 시점과 소요 기간은 선진국마다 차이는 있으나, 완벽한 실증·시연 프로그램을 위한 대규모의 PBG-URL 시설 구축 에는 5 15 년 정도 기간이 소요되었다. 2012년 현재 대부분 국가에서 PBG-URL 시설에서 실증 · 시연프로그램을 수행한 기간은 대체로 30 년 이상의 기간이 소요되는 것으로 확인된 다. 처분과업 수행 일정 계획 수립과 관련하여 주요 현황을 요약하면(Fig. 3):

- PBG-URL프로그램 착수 후, 최소 약 16 34 년 이상 동 안 고유처분시스템의 성능·안전성의 실증·시연 업 무수행

- 실증 - 시연프로그램 등 약 6 12 년 이상 기간의 수행 단계를 거친 후, 최종처분장 부지선정업무에 착수하는 경향이 확인됨

- PBG-URL에서 실증 - 시연 착수 후 약 15 년 이상의 대 국민 이해제고 과정을 거쳐 최종처분장 후보부지선정 의 목표를 달성하였거나 혹은 계획하였음

- 자국의 고유처분시스템의 성능 · 안전성에 대한 실증 · 시연 과업을 완료한 후, 최종처분장 건설허가 신청에 적용하였음

\subsection{2 국내 여건 및 기본방향 제안}

PBG-URL 개발과정에서 가장 중요한 사안은 SF중간저장 시설과 최종처분장의 운영 일정에 대하여 각 시설별 기본개 념과 함께 충분한 연계성을 감안하여야 한다. 세부적으로는 중간저장시설의 세부요건 및 규모와 함께, 처분시스템의 실 증 - 시연 업무 수행과정 및 결과와 상용처분사업 특히, 최종 처분장 후보부지 선정업무와의 조화를 극대화할 수 있는 합 리적인 일정 계획의 수립이다. 전술한 해외 사례의 시사점을 토대로 국내 URL프로그램 구축 및 시행을 위해 개선 혹은 보 완하여야 할 현안문제를 정리하였다.

PBG-URL프로그램은 당연히 전체 상용처분사업 일정과 연계하여 계획 - 추진하여야 할 것이다. 현재 2 차 원자력진 흥위원회(2012. 11)에서 의결한 “제4차원자력진흥종합계획" 에 의하면[1], 정부는 중간저장시설 건설을 위해 정책포럼의 의견을 수용하여, 공론화과정을 거쳐 사용후핵연료의 "국가 관리기본계획”을 수립한 후, 원자력진훙위원회 의결을 거쳐 서, 2015년 이후 중간저장시설 부지를 선정하며, 부지선정 과 건설착수는 공론화위원회 논의결과 등을 반영하여 진행 토록 방침을 정한 바 있다. 한편 정책포럼에서 제시한 중간
저장시설 예상 운영기간을 2050년으로 제안한 바 있으며, 이 시점은 곧 최종처분장 운영 착수 시점을 의미한다. 최종처분 장 운영이 여의치 않을 경우 중간저장시설의 규모 및 제반 개 념은 수정 - 보완이 불가피하게 영향을 받게 되므로 두 시설 의 운영일정은 직접적으로 연계하여 추진되어야 함은 기정 사실이다. 따라서 상용처분사업 측면에서 볼 때, 최종처분장 운영을 위한 준비에 약 37 년의 시간이 주어졌다고 가정할 수 있다. 하지만 전술한 해외사례와 상용처분사업을 위해 필 요한 사전 준비 관련 모든 현안과제를 감안할 때, 마냥 여유 로운 것만은 아니다. 결국 우리의 실정에 부합되는 일정계획 이 수립 · 추진되어야 할 것이다. 이러한 측면에서 PBG-URL 프로그램 구축을 위한 시각을 기술적, 인문 - 사회적 및 제 도적·정책적 측면에서 선후로 추진되어야 할 현안과제들 을 조명하였다:

\section{- 기술적 측면 부문}

처분시스템의 성능 - 안전성 입증을 위한 시공간적 규모 는 engineering 기술개념을 초월한 수준으로 접근하는 방식 에 대한 이해 제고는 사업자는 물론 일반 대중과 함께 특히 정책결정 담장자 및 전문가 등에게 있어 더욱 절실하다. 따 라서 기술적 측면에서 PBG-URL프로그램을 위한 기본개념 으로:

- 상용처분사업은 연구·기술개발과제 접근방식과 동 일한 접근개념으로 추진

- 선호암종의 결정후, PBG-URL 후보부지 선정업무 착 수

- 사업자 고유 처분시스템의 초안(Ver.0) 확립 및 실증 시연용 처분시스템(Ver.01) 구축

- 최종처분장개발을 위한 건설허가 신청 전에 실증·시 연 프로그램 완료

한편 상용처분사업로드맵을 구성하는 세부 수행항목에 대한 기술수목체계는 향후 구체적으로 분류 - 개발하여야 한 다. 또한 도출된 세부 수행항목들은 아래와 같은 기준으로 재분류한 후, 이의 수행 및 목표 달성을 위해 요구되는 필수 선행업무 내용을 도출하여 각 항목 별로 대책 - 수행방안을 분류 - 정리하여야 할 것이다. 즉:

- 현재 기술수준과 문헌자료를 분석 - 검토하여 처분사 업 수행을 위한 단계 별 주요 · 세부 현안과제를 도출 수행항목 목록을 작성하고

- 이 중에서 수정 · 보완없이 적용 가능한 기 개발 항목, 신규로 연구·기술개발이 요구되는 현안과제 등으로 각각 분류한 후 
Dae-seok Bae. et al : Preliminary Review on Function, Needs and Approach of Underground Research Laboratory for Deep Geological Disposal of Spent Nuclear Fuel in Korea

- 처분시스템의 성능 · 안전성에 대한 신뢰성확보 차원 에서 미흡하거나 신규로 연구·기술개발이 필요하다 고 판단되는 항목 도출 및 기술개발로드맵과 세부수 행계획 수립하고

- 처분사업에 직접 적용 가능한 기술항목과 신규로 연 구·기술개발 결과 모두에 대하여 각각 상용사업 업무 수행을 위한 실무수행 기술지침(manual/handbook, $\mathrm{QA}$ 관련지침등) 구축을 위한 수행계획 수립 및 작성 한 후

- PBG-URL 실증 - 시연 결과를 최종처분장 건설허가에 직접 연계 방안 수립

특히 공학적방벽의 성능 입증과 관련한 실증 - 시연 과 정 및 결과는 최종처분장 건설허가에 직접 반영토록 수행단 계에서 인허가기관과 협력체계를 구축하여 해결하여야 할 것이다.

- 정책적·제도적 측면

정책 · 제도적 측면에서 “국가관리기본계획” 수립 시, 공 론화과정에 고유처분시스템의 성능 - 안전성의 실증 - 시연 에 대한 현안과제를 반영한, 처분사업 일정이 적절히 수정되 어야 할 것이다. 즉 중간저장시설 및 처분장 운영과 연계하 여, 중간저장시설 규모 확장 요구가 불가피한 상황에 대한 대 비를 충분히 하여야 할 것이다. 저장시설의 운영기간을 무한 정 뒤로 미루어 계획할 수도 없으며, 운영 종료 후에 처분사 업을 위한 준비 또한 설득력이 없다.

최종처분장 개발사업 수행과정에서 최대 현안과제는 당 연히 최종처분장 후보부지의 결정이다. 이 목표를 달성하기 위해서 가장 선행 및 지속적으로 수행하여야 할 업무는 대국 민 공감대형성 과업으로서 기술현안의 해결과제와 병행개념 (two-track approach) 및 연동하여 접근하는 것이 바람직하 다. 이와 함께 기술적 및 제도적으로 추진 현황에 대한 정보 의 공유와 유기적인 연계체제 유지는 필수적이다. 이는 기술 적 현안과제들이 특정 이해계층에 대하여 기술적인 문제들 가 해결되었다고 해서 인문 - 사회적 여건이 조성되는 것이 아니기 때문이다.

- 인문 · 사회적 측면

원자력산업의 성공적 추진을 위해 다양한 이해당사자들 의 이해 확보는 기술적인 안전성확보와 병행하여 반드시 전 제되어야 함은 모두가 공감하는 대명제이다. 이를 위해 관련 정책결정 및 내용과 함께 모든 업무 및 현안사안에 대하여 모 든 이해당사자들 사이에 정보의 공유와 참여 방안 확립은 필
수 불가결하다. 이는 공론화를 통한 국민이해제고의 가장 기 초적이고 우선 시행되어야 할 현안과제이다. 이를 위해 가능 한 PBG-URL이용 실증프로그램 착수 및 수용분위기를 감안 한 PBG-URL프로그램이 추진되어야 하며, "국가관리기본계 획”의 일환으로 위상 정립하는 것이 바람직하다.

한편 모든 PBG-URL 프로그램 및 수행과정 전반에 걸쳐 서 주요 사안에 대한 의사결정 시, 지역사회의 의견수렴은 필 수적이며, 참여기회를 확대하여 스스로 주인의식을 갖도록 추진전략 기조 유지가 필요하다. 또한 국제적인 수준의 선진 국 대열에 합류하기 위한 PBG-URL 프로그램 구축, 추진방 향 또한 인문 - 사회적 측면에서 접근하는 자게가 필요하다:

- 지역전문가(local expert)의 참여 기회 발굴 - 확대

- 국내외 전문가집단들의 참여 유도, 활성화

- 대국민 이해제고 부문의 확대 및 활성화

- IAEA의 URF network에 적극적 동참 등 국제협력 강화

\section{6. 토의 및 결언}

\section{1 $\mathrm{PBG}-\mathrm{URL}$ 의 전략적 역할과 기대효과}

우리나라는 중저준위폐기물 처분장부지 확보업무에만 20 여 년 이상의 장기간에 걸쳐, 지역주민들의 갈등과 책임 수행기관의 변동 등 많은 어려움과 시행-착오를 겪었다. 다 행히 원자력에 대한 국민이해 분위기가 과거와는 달리 다양 한 이해당사자들로부터 관심의 변화는 보이고 있어, 국민의 곁으로 상당히 다가와 있다고 느껴진다. 하지만 여전히 원자 력에 대한 저항과 이해제고를 위해 해결하여야 할 현안문제 들이 산재해 있다.

URL 시설은 다양한 목적을 위해 필요하며, 업무의 특성 이 양호한 접근, 목표 및 적용이 분명하여야 함은 물론 근본 적으로 연구 개념의 성격을 가지고 있다. URL시설의 중요 성은 유형에 따라 상대적인 측면에서 유연한 장점을 가진 다. PBG-URL시설에서 수행 가능한 실증 - 시연프로그램 수 립 단계에서 처분시스템의 특성과 관련하여 세 가지 부문 즉, 현안과제의 분류, 프로그램 결정 전략 및 계획 수립 과정 등 의 측면을 반영하여야 한다.

PBG-URL은 잠재적인 처분장 부지특성평가에 대한 이 해제고와 처분적합성평가에 필요할 뿐만 아니라 처분시스 템의 개념 개발 및 대안의 시험 등에도 필요하다. 성능평가 를 수행하기 위하여 다양한 범위와 현상이 모델링되어야 하 
Dae-seok Bae. et al : Preliminary Review on Function, Needs and Approach of Underground Research Laboratory for Deep Geological Disposal of Spent Nuclear Fuel in Korea

고 또한 새로운 모델의 개발도 요구된다. PBG- URL시설의 지원에도 불구하고, 성능평가에 요구되는 시공간적인 규모 에 따른 이러한 모델의 시험이 실현 불가능하게 될 수도 있 다. 하지만 PBG-URL시설에서 이들 모델들의 기본개념은 관 련 현상들을 고려한 모델이 시험될 수 있도록 설계되어야 하 고, 해당 지하공동 규모와 관련 암석구조과 동일한 현장 조 건에 적용 가능하여야 한다는 것이다(Table 4). PBG-URL에 서 수행한 업무는 아래와 같은 불가피한 제약조건 또한 감안 하여야 한다[5, 11]:

- PBG-URL 내에서 암반체적 내의 시· 공간적 변화특 성과 범위를 결정하는 제반 시험은 절대적인 해결책 이 아니라 모사에 의한 간접적인 평가방법으로 이해 하여야 한다.

- 특정 인자에 대하여 수 센티미터 이상 규모의 신뢰성 있는 측정은 불가능할 수도 있지만, 모델실증과 관련 하여 수용 가능한 수준의 지원을 위해 충분한 자료들 이 요구될 수도 있다.

- 시험 혹은 조사 대상 암반체적은 최종처분장에서 요구 되는 체적에 비해 매우 작은 규모가 될 것이다. 그럼에 도 불구하고, 처분장으로 수용 가능한 암반체적 이상 의 규모에 대하여 충분한 자료의 제공을 필요로 한다.

- 실현 가능한 시험의 장애등 제한조건들은 시간 종속적 인 규모로 수정 · 보완이 요구된다.

처분개념의 설계 대안들에 대한 최종 결정을 위해서, PBG-URL과 실제 처분장에서의 결과들을 통합 평가하는 과 정이 필요하다. 또한 PBG-URL은 심층처분개념에 대한 신뢰
성확보를 위해 지원업무에 기술적 측면과 함께 인문 - 사회 적측면에서 가장 큰 기능과 역할을 하게 된다. 즉:

- 최종처분장 개발을 위해서 단계적 - 체계적 접근방법 과 적정한 절차가 가장 필수적이며, 이를 통해 객관성 에 대한 가치가 확보된다.

- 국내외 방사성폐기물관리 주체들과 함께, 과학기술 전 문분야를 포함한 지역사회에서 다양한 이해당사자들 을 대상으로 분야 - 계층간 의사소통과 정보교류의 장 으로서 기여를 한다.

- 실증과업을 포함한 상용처분사업 전 과정에서 모든 이 해집단 등의 이해증진 효과가 기대되며, 과감하고 개 척적 성격의 과업에 직접적으로 적용 가능하다.

- 모든 상용처분사업 프로그램은 추진과정에서 충분한 유연성 유지가 필수적이며, 이를 통하여 추가적인 자 료 축적, 성능 - 안전성 평가와 확인과정에서 규제 및 제도적 측면, 그리고 참여 요구되는 사회 구성 체제 등 에 대하여 적극적인 대처가 가능하게 한다.

- 현장 실증 - 시연 업무는 신뢰성확보의 일환으로 추진 되는 일련의 절차와 연계된다. 최종처분장 개발업무와 관련한 부지특성평가 및 연구·기술개발 수행으로 자 료 확보 · 축적을 통하여 상호 연계성 프로그램 수립을 가능토록 한다.

- 시설 및 주변지역의 장기모니터링 업무는 처분시스 템의 성능·안전성 입증에 중요한 역할과 기능을 하 게 된다.

- 모니터링시스템의 설계 및 운영에 관한 내용과 특정

Table 4. Factors to consider in designing generic and site-specific URL programmes

\begin{tabular}{|c|c|}
\hline Generic/PBG-URL & SS-URL \\
\hline - Primarily a research facility & - A real disposal site \\
\hline - Select site that is both relevant and scientifically interesting and & - Minimize perturbations to geosphere \\
\hline able to be modelled & - Rigorous Quality Assurance programme \\
\hline - Emphasis on scientific development & - Construction techniques generally limited to those applicable to \\
\hline - Needed to develop and test methodology & repository concept, but also testing of construction techniques \\
\hline $\begin{array}{l}\text { - Needed to obtain generic data unobtainable from surface-based } \\
\text { R\&D }\end{array}$ & $\begin{array}{l}\text { - Scientific programme designed to minimize uncertainties from } \\
\text { surface-based investigations }\end{array}$ \\
\hline $\begin{array}{l}\text { - Very useful for demonstration and communication of ideas and } \\
\text { concepts }\end{array}$ & $\begin{array}{l}\text { - Collection of data relevant to detailed design and licensing safety } \\
\text { assessment Demonstration of repository concept at full, or other }\end{array}$ \\
\hline - Guarantee of no repository construction? & pertinent scales and optimization of disposal technology \\
\hline
\end{tabular}


Dae-seok Bae. et al : Preliminary Review on Function, Needs and Approach of Underground Research Laboratory for Deep Geological Disposal of Spent Nuclear Fuel in Korea

모니터링 목표들은 PBG-URL프로그램의 초기단계와 잘 일치하도록 하여야 한다.

한편 SS-URL시설은 최종처분장 후보부지 부지특성평가 프로그램 상에서 통상적인 업무의 일환으로 이해된다. 세부 수행계획 상에서 의사결정 행위는 “적정 처분환경”이라는 목 표에 따라 좌우되며, 이 결정은 SS-URL프로그램 추진과정에 서 그 목표에 도달하여야 한다. 최종처분장부지 특성평가 및 성능 · 안전성평가 과정에서 제기되는 불확실성에 관한 다양 한 현안문제들은 SS-URL시설의 개발과 운영에 의해서만 해 결할 수 있다.

한편 우리나라에서 최종처분장 부지내에서 SS-URL을 이 용한 처분시스템의 성능 - 안전성의 입증 방법으로 접근은 실현 가능성이 거의 희박하다. 우선 중 - 저준위 경주처분장 부지 선정사례를 돌이켜 볼 때, 부지선정업무에 예측 불가능 할 정도의 장기간이 소요되며, 이 기간 동안 어떠한 처분시 스템의 성능 - 안전성의 입증 행위가 이루어질 수 없어 장기 간 기술이전/전수에 공백기가 초래할 우려가 있다. 더욱이 처분시스템의 성능 - 안전성에 대한 실증-시연 업무는 경 제성 논리의 대상이 될 수 없는 필수 불가결한 현안과제임 을 명심하여야 한다.

\section{2 결언}

처분시스템은 공학적방벽과 천연방벽으로 구성되는 다 중방벽개념으로서 이 두 방벽시스템의 개념은 자국 고유의 자연환경 특성을 근간으로 한 개념이다. 공학적방벽은 기술 적으로 가장 안정되고 경제적인 효율성을 기반으로 개념을 구축하고, 재료와 관련 기술지침을 개발하며, 이에 대한 성 능·안전성은 실증·시연 시험을 통하여 입증되어져야 한 다. 천연방벽은 자국 고유의 자연환경 특성을 반영하여 선호 암종을 결정한 후, 심지층환경의 처분적합성을 입증하고 이 와 관련 처분적합성지표를 개발, 제시하여야 한다. 또한 공 학적방벽의 성능 - 안전성 요건에 상호영향을 미치는 특성도 함께 정의되어야 한다.

SS-URL 시설은 최종처분시설개발 과정에서 필연적인 절 차임에도 불구하고, PBG-URL을 통한 성능 - 안전성 입증 절 차 또한 불가피한 과정이다. 다만, 기술적으로 상당히 집중 적인 추진이 필요하다는 것을 강조한다. 전술한 전제조건을 기반으로 현안 문제들에 대한 대책과 추진 방안을 수립하는 차원에서, 우리나라에서 PBG-URL 시설의 필요성을 기술적인문사회적 측면에서 정리하면:

- 처분시스템의 성능 - 안전성을 PBG-URL에서 입증한
후, 최종처분장 건설허가에 적용 가능하며, 지속적으 로 성능 · 안전성에 대한 신뢰성을 제고하여야 한다.

- 처분장 안전성확보를 위해 PBG-URL시설을 이용한 safety case 개발 - 확보는 필수 사항이다.

- 자국 고유의 선호암종에 대한 처분적합성 입증 및 적 합성지표 개발은 PBG-URL에서 완성되어야 한다.

- PBG-URL에서 성능 - 안전성이 입증된 처분시스템은 최종처분장부지 SS-URL에서 일부 현안과제에 제한적 으로 실증함으로써, 재실증/중복실증의 부담을 충분 히 저감할 수 있다.

- PBG-URL에서 건설 · 운영 전문 인력의 교육 및 훈련 은 처분안전성 확보를 위한 가장 근본적이고 기초적 인 업무이다.

- 최종처분장 부지선정 업무 지원 등 상용처분사업 전반 에 걸쳐 다양한 이해계층을 위한 대국민 이해제고의 장 으로 활용에 필수적이다.

- 폐광산 등 기존의 지하공간 시설을 이용한 실증-시 연 과정과 결과에 대한 신뢰성과 효율성은 기대하기 어렵다.

무엇보다 중요한 핵심 사안은 자국 고유처분시스템의 성 능 - 안전성에 대한 입증과정(실증 - 시연)은 반드시 거쳐야 하는 절차로 이해하여야 한다. 상용처분사업의 효율적인 추 진을 위해 다양한 이해계층의 의견수렴을 통한 공론화와 대 화 · 토론의 도구로 매우 효과적임과 동시에 신뢰성확보 수 단으로 필수 불가결한 과정이다. 특히 최종처분장 후보부지 선정업무 수행에 선행하거나 혹은 병행함으로써 국민 공론 화를 통한 공감대 구축 과정에 중심적인 역할을 할 수 있다.

전술한 PBG-URL 시설의 확보 및 운영 필요성을 토대로 우리나라의 현실에 부합하는 PBG-URL 위상 및 기능에 대 한 개념이 정립되어야 할 것으로 판단된다. PBG-URL 시설 의 필요성에 대한 다양한 이해집단들의 이해제고와 함께 지 원이 수반되어야 효율적이고 효과적인 상용 처분사업이 실 현될 것이다.

해외 선진국의 사례와 국내 여건을 고려한 PBG-URL의 필요성과 관련하여 상용처분사업 수행을 위해 확립하여야 할 전제조건으로서;

- 국내외 심층처분 관련 제반 여건을 고려한 제도적 장 치 구축되어야 한다.

- 자국 고유의 선호암종이 결정되어야 한다.

- 외국의 처분시스템을 우리나라에 직접 적용 가능성은 희박하며, 자국의 지질환경(천연방벽) 및 이에 적합한 공학적방벽으로 구성된 고유처분시스템을 개발 및 확 
보하여야 한다.

- 고유처분시스템의 성능 · 안전성에 대한 실증과 심층 처분장 건설·운영 기술·장비 개발 등 이의 실현 가 능성에 대한 시연/검증은 필수 과정이다.

또한 PBG-URL시설을 이용한 처분시스템의 실증 - 시연 을 통하여 처분시스템의 성능 - 안전성을 입증과 함께, 처분 시스템을 구성하는 공학적방벽과 천연방벽의 처분요건에 대 한 세부 기술지침을 개발 및 정의 - 제시하는 것이다. 이와 병 행하여 국민이해 제고에 가장 심혈을 기울여야 한다. PBG$\mathrm{URL}$ 의 접근 철학에서 큰 축을 구성하는 분야가 다양한 이해 계층에 대한 이해제고 및 공감대 형성과업이다. 이와 동시에 처분장 후보부지 선정 업무를 단계적 및 신중하게 접근하여 야 한다. 이러한 과정이 마무리되면서 최종처분장부지에서 고준위폐기물 처분시설의 개발업무가 시작되는 것이다. 따 라서 우리나라의 처분안전성 확보를 위한 URL 계획 수립단 계에서 PBG-/SS-URL의 역할과 기능에 있어서 필요성과 차 별화를 충분히 고려함으로써, URL의 활용 방안에 대한 타당 성 확보 및 다양한 이해계층을 대상으로 신뢰성 제고에 자신 감을 가지고 적극적으로 대처해야 할 것으로 판단된다.

\section{감사의 글}

본 연구는 2012 2015년도산업통상자원 부의 재원으로 한 국에너지기술평가원(KETEP)의 지원(No. 2012171020001D) 을 받아 수행하였습니다.

\section{REFERENCES}

[1] MKE-KAEPC, The 4th National Plan for Korea Atomic Energy Promotion 2012 2016, The 2nd Committee of KAEPC (Korea Atomic Energy Promotion Commission), Nov. 2012, Ministry of Knowledge Economy (2012).

[2] NEA "The Handling of Timescales in Assessing PostClosure Safety", Docket No. OAR-2005-0083-0046 (2004).

[3] S.H. Lee and Y.S. Hwang, "Technical Standards on the Safety Assessment of a HLW Repository in Other Countries", J. Korean Radioact. Waste Soc., 7(3), pp. 183-190 (2009).

[4] D.S. Bae, Y.K. Koh, J.W. Park, J.B. Park and J.S
Song, "Study on Basic Requirements of Geoscientific Area for the Deep Geological Repository of Spent Nuclear Fuel in Korea”, J. Korean Radioact. Waste Soc., 10(1), pp. 63-75 (2012).

[5] NEA, Going Underground for Testing, Characterization and Demonstration, NEA/RWM(2001)6, OECD, Paris (2001).

[6] OECD/NEA, The Role of Underground Laboratories in Nuclear Waste Disposal Programmes, p. 47 (2001).

[7] SKB, Handling and final disposal of nuclear waste, Hard Rock Laboratory, Background report to R\&DProgrammes 89, p. 59 (1989).

[8] SKB, Äspö Hard Rock Laboratory - Planning Report for 2010, International Progress Report, p. 99, SKB IPR-10-06 (2010).

[9] JAEA, Construction Work of Mizunami Underground Research Laboratory Outline of Construction (2003).

[10] POSIVA, ONKALO Underground Characterization and Research Programme (UCRP), POSIVA OY, FIN-27160 OLKILUOTO, FINLAND (2003).

[11] DOE/RW-0573, Yucca Mountain Repository License Application-Safety Analysis Report.

[12] IAEA, Factors Affecting Pubic and Political Acceptance for the Implementation of Geological Disposal, IAEA-TECDOC-1566, IAEA, Vienna (2007).

[13] N.A. Chapman, I.G. McKinley and M.D. Hill, The Geological Disposal of Nuclear Waste, p. 280, John Wiley \& Sons(1987)

[14] C. Fairhurst, F. Gera, P. Gnirk, M. Gray and B. Stillborg, International Stripa Project, 1980-1992-Overview 1(1), Executive Summary, p. 106, OECD/NEA (1993).

[15] SKB, Hard Rock Laboratory, R\&D-PROGRAMME 89-Background Report, Handling and final disposal of nuclear waste, p. 106, SKB (1989).

[16] SKB, Treatment and final disposal of nuclear waste - Äspö Hard Rock Laboratory, Background report to R\&D-Programmes 92, p. 54, SKB (1992).

[17] Andra, Evaluation of the feasibility of a geological repository in an argillaceous formation, Meuse/ 
Dae-seok Bae. et al : Preliminary Review on Function, Needs and Approach of Underground Research Laboratory for Deep Geological Disposal of Spent Nuclear Fuel in Korea

Haute-Marne site, p. 241 , Dossier 2005 Argile Synthesis(2005).

[18] ANDRA, Assets of granite formations for deep geological disposal, p. 241 , Dossier 2005 Granite Synthesis(2005).

[19] BMWi, Final Disposal of High-level Radioactive Waste in Germany - The Gorleben Repository Project, p. 62, Federal Ministry of Economics and Technology (BMWi)(2008).

[20] JNC, H12: Project to Establish the Scientific and Technical Basis for HLW Disposal in Japan, Projedt Overview Report, Second Progress Report on Research and Development for the Geological Disposal of HLW in Japan, JNC TN1410 2000-001, p. 395, JNC(2000).

[21] SKB, Design and production of the KBS-3 repository, SKB-TR-10-12 (2010).

[22] M. Juvankoski and N. Marcos, Design basis for buffer components, POSIVA Working Report 2009132 (2010).

[23] AkEnd, Members of the Committee on a Site Selection Procedure for Repository Sites, Site Selection Procedure for Repository Sites; Recommendations of the AkEnd-Committee on a Site Selection Procedure for Repository Sites, p. 248, AkEnd (Arbeitskreis Auswahlver-faren Endlagerstandorte), Germany(2002).

[24] Johan Andersson, Anders Ström, Christer Svemar, Karl-Erik Almén and Lars O Ericsson, What requirements does the KBS-3 repository make on the host rock? Geoscientific suitability indicators and criteria for siting and site evaluation, SKB/TR00-12 (2000).

[25] IAEA, International Basic Safety Standards for Protection against Ionizing Radiation and for the Safety of Radiation Sources, Safety Series No. 115, IAEA, Vienna (1996).

[26] NEA, Post-closure Safety Case for Geological Repositories, Nature and Purpose, NEA No. 3679, OECD, Paris (2004a).

[27] NEA, Stepwise Approach to Decision Making for Long-term Radioactive Waste Management Issues and Guiding Principles, NEA No. 4429, OECD,
Paris (2004b).

[28] IAEA, The use of scientific and technical results from underground research laboratory investigations for the geological disposal of radioactive waste, p. 67 , IAEA-TECDOC-1243 (2001).

[29] POSIVA, Disposal of spent fuel in Olkiluoto bedrock - Programme for research, development and technical design for the pre-construction phase, $\mathrm{p}$. 152, Posiva 2000-14, Posiva Oy (2000).

[30] P. Anttila, M. Arenius, K. Haapala, J. Hansen, P. Hellä, T. Jalonen, J. Lahdenperä, T. Lyytinen, S. Mellanen, P. Vuorio and T. Äikäs, Testing and Demonstrations in ONKALO -Aims and Needs, p. 115, Working Report 2009-24, POSIVA(2009).

[31] SKB, Aspo Hard Rock Laboratory, Annual report 2010, Svensk Karnbranslehantering AB, Swedish Nuclear Fuel and Waste Management Co., Stockholm (2011).

[32] KINS, Generic Criteria for Deep Geological Disposal Facility of High-level Radioactive Waste (draft, under discussion and consensus), unpublished (2011).

[33] IAEA, REPORT of the WATRP review team on the Research and Development Programme for the Disposal of High Level Waste in Korea, Convened by the International Atomic Energy Agency at the request of the Korea Atomic Energy Research Institute, Daejon, Republic of Korea, 28 Oct. 1 Nov. 2002, p. 28, IAEA, unpublished (2002).

[34] KRMC, Concept Development of Underground Research Laboratory for Deep Disposal System in Korea, p. 327, KAERI-KRMC(2011).

[35] IAEA, Siting of Geological Disposal Facilities, A Safety Guide, A Publication within the RADWASS Program, Safety Series No. 111-G-4.1, IAEA, Vienna (1994). 